\title{
The synthetic theory of evolution: general problems and the German contribution to the synthesis
}

\author{
Wolf-Ernst Reif ${ }^{1}$, Thomas Junker ${ }^{2}$, Uwe Hoßfeld ${ }^{3}$ \\ ${ }^{1}$ Institut und Museum für Geologie und Paläontologie, Eberhard-Karls-Universität \\ Tübingen, Sigwartstraße 10, D-72074 Tübingen \\ ${ }^{2}$ Lehrstuhl für Ethik in den Biowissenschaften, Eberhard-Karls-Universität Tübingen, \\ D-72074 Tübingen \\ ${ }^{3}$ Institut für Geschichte der Medizin, Naturwissenschaft und Technik, Ernst-Haeckel- \\ Haus, Friedrich-Schiller-Universität Jena, D-07745 Jena
}

Address for correspondence: Prof. Dr. Wolf-Ernst Reif, Institut und Museum für Geologie und Paläontologie, Sigwartstraße 10, (priv.: Eschenweg 1), D-72076 Tübingen, Tel.: 0 7071/2 9724 91, priv.: 0 7071/65316, e-mail: wolf-ernst.reif@uni-tuebingen.de, e-mail priv.: wolf-ernst.reif@t-online.de

Received: November 4, 1999; accepted: January 10, 2000

Key words: history of biology, philosophy of science, macroevolution, natural selection, scientific revolution.

Summary: A metatheoretical and historiographical re-analysis of the Evolutionary Synthesis (the process) and the Synthetic Theory (the result) leads to the following conclusion: The Synthetic Theory is not a reductionistic, but rather a structuralistic theory with a limited range of relevant hierarchical levels. Historically the Synthesis was not a sudden event but a rational long-term project carried out between 1930 and 1950 by a large number of biologists in several countries. In the second part of our paper the contributions of several German biologists to the Synthesis are analyzed.

\section{Introduction}

One of the most deplorable gaps in our knowledge of the history of the Synthetic Theory is its international character. Since the early years of the Synthetic Theory different versions with regards to its social, national and disciplinary range have been advanced. In pluralistic (soft) interpretations the international character of the Synthesis is stressed, various biological disciplines are included and a rather comprehensive list of architects of the Synthesis is given. Although this broad outlook never completely vanished, in the $1980 \mathrm{~s}$ and $1990 \mathrm{~s}$ hard versions became increasingly dominant. In these narrow interpretations only few British and American biologists are mentioned as architects. The history of the Synthesis is written 
without reference to international (especially Russian and German) contributions. The American and British 'architects' of the Synthesis have been treated quite extensively in the literature, and there exist some (but definitely not enough) papers on the Russian accomplishments (Adams 1967, 1970, 1980 a, b, 1994; Dobzhansky 1980; Zavadskij 1974; Zavadskij \& Kolchinsky 1977; Mikulinsky \& Kolchinsky 1983; Gall 1997, 2000; Kolchinsky 1994, 1997, 1999, 2000 a, 2000 b; Popov 1998). Especially the German contributions are unknown or controversial, because they have not been carefully analyzed in Mayr \& Provine (1980/1998) and are totally neglected by most historiographers of the Synthesis since then (see e.g. Beatty 1986; Cain 1992, 1993, 1994; Smocovitis 1992, 1996; Ruse 1996).

The now mostly accepted understanding of the development of the Synthetic Theory is based on the results of The Evolutionary Synthesis by Mayr and Provine (1980/1998). According to this understanding the Synthetic Theory is based on six books: Genetics and the Origin of Species (1937) by the American (Russian born) population biologist Theodosius Dobzhansky; Evolution: The Modern Synthesis (1942) by the British developmental biologist Julian Huxley; Systematics and the Origin of Species (1942) by the American (German born) (bird-)systematist Ernst Mayr; Tempo and Mode in Evolution (1944) by the American (mammal-)paleontologist George Gaylord Simpson; Neuere Probleme der Abstammungslebre. Die transspezifische Evolution (1947) by the German zoologist Bernhard Rensch; and Variation and Evolution in Plants (1950) by the American botanist G. Ledyard Stebbins. Our paper will demonstrate that this historical view is too narrow and misleading. In addition we will show that current discussions of the Synthesis (the process that led to the Synthetic Theory) and of its result (namely the Synthetic Theory) are plagued by important historiographic and philosophical uncertainties which are partly due to the fact that the history of the Synthesis in the various countries (U. K., USA, Germany, USSR, France) was never carefully analyzed and that its historiography was strongly influenced by some of the architects of the Synthesis (who disagreed among each other). Biologists and philosophers face numerous metatheoretical problems with the Synthetic Theory: How can if be defined? What is its logical status? How can it be distinguished from its historical precursors? How can it be distinguished from competing theories? Can it be refuted, expanded or refined? etc.

In Chapter II, we delineate three major historical stages of Darwin's theory of evolution. Chapter III is an account of the historiography of the Synthesis and its problems. In Chapters IV to VI criteria for the Synthesis are suggested, its structure is analyzed and a temporal distinction introduced. Chapters VII and VIII deal with significant contributions to the Synthesis by German biologists and their lack of international and local influence after World War II. 


\section{Darwinism, Neo-Darwinism, Synthetic Theory, and Evolu- tionary Synthesis}

Both, some defenders and some critics of the current version of the Darwinian evolutionary theory call it neo-Darwinism (e.g. Rensch 1980, p. 284; Gould 1980 b, p. 119; Charlesworth et al. 1982; Hecht \& Hoffmann 1986; Smocovitis 1996, p. XII). This is either a sloppiness in terminology or an implicit rejection of the Synthetic Theory as a new step in the development of the Darwinian theory. Both cases necessarily lead to confusion. As early as 1949 G. G. Simpson has criticized that the term 'neo-Darwinian theory' for the Synthetic Theory is confusing and a misnomer (Simpson 1949 b, p. 277 n.; see also Caplan 1978; Grant 1983, p. 150; Junker 1999).

Most biologists and historians of biology agree that Darwin developed theories concerning two different aspects of organic evolution: Descent (i.e. the evolutionary and phylogenetic process as such) and evolutionary mechanisms (i.e. the mechanisms of evolutionary change and of organic diversity). Ernst Mayr distinguishes five different Darwinian theories: (1) Evolution as such, (2) evolution by common descent, (3) gradualness of evolution, (4) natural selection and (5) populational speciation (1982, p. $505 \mathrm{ff}$.). We will not use his classification in this paper, despite its merits. The theory of descent was accepted by most biologists during Darwin's life-time or soon thereafter. On the other hand the theories of selection, speciation and gradualism ('theory of evolution', for the sake of brevity) have been controversial ever since Darwin (Bowler 1983, 1984, 1988; Reif 1983, 1986; Junker 1989, 1995, 1998 a).

Most biologists and historians of biology agree that at least three major historical stages in the development of the theory of evolution can be distinguished:

a) Darwinism: This is Darwin's theory, which emphasized the power of selection and accepted both hard and soft ("Lamarckian") inheritance.

b) Neo-Darwinism: This term was coined by George John Romanes to denote the "the pure theory of natural selection to the exclusion of any supplementary theory" (Romanes 1895, p. 12), presented by Alfred Russel Wallace and especially August Weismann. Weismann (1885) had refuted both Lamarckism and pangenesis and emphasized the selection and perpetuation of favorable characters.

c) The Synthetic Theory of Evolution originated in the early 1930s, or according to many authors from 1937 to 1950 . The historical processes that led to the Synthetic Theory and its exact content will be discussed below. It is sufficient to say here that Weismann's neo-Darwinism and the Synthetic Theory cannot be equated. In contrast to neo-Darwinism the Synthetic Theory includes modern genetics, population genetics, systematics and theories of speciation and macroevolution (based on paleontology, 
comparative morphology and developmental biology). In addition, within the Synthesis non-selectionist factors of evolution, especially isolation, chance events, and population size are emphasized. Selection is regarded as important, but only as one of several evolutionary factors (Gayon 1998, p. 319-354; for an alternative chronology of the history of Darwinism see Mayr 1998).

'Evolutionary Synthesis' is defined here as the process during which the Synthetic Theory of Evolution was developed. 'Synthesis' is a word that involves process-product ambiguity. Hence we distinguish between: (1) Evolutionary Synthesis (the process) and (2) Synthetic Theory (the product) (see Shapere 1980, p. 395; Junker 1999).

\section{Historiography of the Synthesis}

The term 'Modern' or 'Evolutionary Synthesis' is derived from the title of Huxley's book Evolution: The Modern Synthesis (1942). The term 'Synthetic Theory' was first used by Simpson (1949 a, p. 277). The first authors who wrote about the 'Synthesis' were several American biologists (mainly Mayr and Simpson) who regarded themselves as major architects of this Synthesis. They propagated several ideas: (1) The Synthetic Theory is a completely new paradigm of the theory of evolution. (2) The Synthesis was a unique process in the history of biology. (3) The Synthesis was made possible by a reconciliation of theoretical (mathematical), experimental and naturalistic (= field observations) methods of biology (see Simpson 1949 b, p. 277 n.; Mayr 1954, p. 57; Mayr 1959, pp. 4-5; Mayr 1963, p. 1; Simpson 1978, p. 114; Simpson in Mayr \& Provine 1980, p. 456-7; Mayr 1984; and below).

The historiographical accounts advanced by the architects of the Synthesis lead to several problems: The architects did not agree among themselves about the character and the importance of their respective contributions to the Synthesis (see Mayr 1980 c; Junker 1996 a; Smocovitis 1996, p. 31 for quotations from the correspondence between Simpson and Mayr). Philosophers had problems to understand the theoretical and metatheoretical aspects of the Synthetic Theory: What was the content of the Synthetic Theory? What kind of a theory is the Synthetic Theory? (see Shapere 1980).

Historians of biology did not understand what kind of a historical process was meant by the Synthesis: Was it a scientific revolution, an elimination of unfruitful research programs or of contradictory theories etc.? Smocovitis calls the Synthesis "one of the most central and enigmatic episodes $[\ldots]$, one of the most vexing problems [...], one of the most central and notorious problems [...] in the history of biology" which caused "confusion as soon as attempts were made to assess its status” (1996, pp. XI, XII, 19, 22, 42-43). For Burian the Synthesis is a "moving target" (1988, p. 250) 
and the discussion by Orzack and Gould (1981) gives an example of how difficult it is discuss theoretical aspects within the framework of the historiography of the Synthesis. Some of the historical and philosophical problems seem to have arisen simply by the predominance of hard interpretations of the Synthesis!

So far no systematic and theory- and philosophy-oriented historiography of the Evolutionary Synthesis has been presented. The book by Mayr \& Provine (1980/1998) consists only partly of professional analyses of developments in certain disciplines and certain countries. Other contributions are (undoubtedly valuable) recollections of biologists who had worked during the years of the Synthesis. Smocovitis (1996) provides interesting details about the discussion of the historiography of the Synthesis but no systematic historical or philosophical analysis. In our account we will focus on important historiographical aspects of with respect to philosophical problems and with respect to what we call the "hardening of the historiography of the Synthesis", i. e. the neglect of the German and Russian contributions to the Synthesis in widespread historiographical interpretations.

\section{Jepsen, Mayr and Simpson 1949}

The first symposium that discussed the new results was Genetics, Paleontology, and Evolution, an international conference organized in January 1947 by the "Committee on Common Problems of Genetics, Paleontology, and Systematics" of the National Research Council and edited 1949 by Jepsen, Mayr, and Simpson. Only American biologists and paleontologists were members of the committee. Commentators of this conference later expressed their surprise that the strong discrepancies between experimental and field biology, between genetics, systematics and paleontology etc. that had dominated discussions before the war had almost completely vanished (Mayr 1980 a, p. 42). In the foreword Jepsen, vertebrate paleontologist and senior editor, stated that the publication signified the formal completion of the work of the committee which had been established in 1943. Its purpose had been to "bring about a meeting of minds in the territory between the fields of genetics and paleontology" (p. v). Jepsen emphasizes that the book is "not a single synthesis of its three titular subjects" (p. viii); rather every author presented his ideas in the light of "penetrating, and sometimes embarrassing questions and comments" (p. viii) of practitioners of other fields.

To summarize: The editors did not use the term 'Synthetic Theory' and, most notably, did not regard the Synthesis as completed. The clearly stated purpose was (exactly as in the books by Zimmermann 1930, 1938; HaaseBessell $1941 \mathrm{a}$, b; Heberer $1943 \mathrm{a}$; see below) a reconciliation of systematics, comparative morphology and comparative embryology and paleontology on the one hand and genetics on the other hand. 


\section{Dobzhansky 1949}

Dobzhansky's foreword to the English translation of Schmalhausen's Factors of Evolution (1949/1986) is a very important document of the early reception of the Synthetic Theory. Dobzhansky speaks of an "upsurge of activity in evolutionary biology unprecedented since the time immediately following the publication of Darwin's 'Origin of Species'" which was caused "by convergence and unification of the contributions to evolutionary thought coming from various biologic disciplines. [...] Genetics, systematics, comparative morphology and embryology, paleontology, and ecology have all been profoundly influenced by and have made important contributions to evolutionary thought. [...] A trend toward unification and synthesis [of the different disciplines] has set in" (p. xv). Dobzhansky lists several "synthetic treatments": Dobzhansky (1937), Mayr (1942), Simpson (1944), Huxley (1942) and Rensch (1947) and comes to the conclusion: "The view of evolution which emerges from all these several treatments is very largely the same. We have arrived at a biologic synthesis. The book of I. I. Schmalhausen advances the synthetic treatment of evolution" (p. xv).

It is important to note that Dobzhansky did not speak of a completed Synthetic Theory of Evolution. Rather the "biologic synthesis" had overcome the unfamiliarity and mutual isolation of many different biological disciplines. The "biologic synthesis" is not so much a theory than the basis of new fruitful research. Dobzhansky mentions Mayr, Simpson, Huxley, Rensch and himself not as authors of a new paradigm (to the exclusion of other biologists) but only as authors of "synthetic treatments", i.e. bookauthors who started from their own field and incorporated results of adjacent fields aiming at a reconciliation of an evolutionary perspective of different evolutionary disciplines.

\section{Simpson 1949}

To our knowledge Simpson was the first author who regarded the Synthesis as completed, who used the term "Synthetic Theory", and who summarized the outcome of the historical process (1949; see Laporte 1983, 1990, 1991, 1994; Junker 1999, in print b). For the present discussion two aspects are important: Simpson perceives the Synthetic Theory as an international movement comprising biologists from six countries and of various biological disciplines:

"The synthetic theory has no Darwin, being in its nature the work of many different hands. To mention any of these is to be culpable of important omissions, but if only to indicate the breadth of the synthesis it may be noted that among the many contributors have been: in England, Fisher, Haldane, Huxley, Darlington, Waddington, and Ford; in the 
United States, Wright, Muller, Dobzhansky, Mayr, Dice, and Stebbins; in Germany, Timoféeff-Ressovsky and Rensch; in the Soviet Union, Chetverykov and Dubinin; in France, Teissier; in Italy, Buzzati-Traverso" (Simpson 1949, p. 277-278).

Simpson did not define the term 'Synthetic Theory'. It is remarkable that Simpson mentioned his own name only in a footnote and that he did not distinguish between the historical phases of preparation and formation of the Synthetic Theory (see chapter VI). In this respect his concept differed from Mayr's and it did not prevent the interpretation that the development of theoretical population genetics (around 1930 by Fisher, Haldane, and Wright) was the real synthesis (e.g. Wright 1960, 1967; Beatty 1986). In contrast to Jepsen Simpson regarded the Synthetic Theory as a "unified theory" "which is capable of facing all the classic problems of the history of life and of providing a causalistic solution of each" (1949, p. 278, our emphasis). This first account of the origins of the "Synthetic Theory" as a historical entity is clearly pluralistic with regards to the architects and their national origin.

\section{Dobzhansky 1951 and 1955}

In two reviews with some historical comments (1951, 1955), Dobzhansky did not use the term "Synthetic Theory" but emphasized the historical importance of mathematical population genetics for experimental and historical population genetics. In other word he saw a continuum of the research programs that had started no later than S. S. Chetverikov (1926; see Dobzhansky 1959) and that had led to the success of evolutionary biology after World War II. This coincides completely with the view of N. W. Timoféeff-Ressovsky (see below, chapter VII).

\section{Haldane 1953}

In the same years J. B.S. Haldane already envisioned a new synthesis, which would lead to a new theory of evolution. As representatives of the "currently accepted synthesis" he mentions five biologists: "The current instar of the evolution theory may be defined by such books as those of Huxley, Simpson, Dobzhansky, Mayr and Stebbins" (1953, p. XVIIIXIX).

\section{Mayr 1959}

In 1959 Mayr emphasized that the Synthesis was a paradigm shift from typological thinking to populational thinking and that - in contrast to the view held by geneticists - the naturalists had played a major role in the paradigm shift. Mayr talked about the Synthetic Theory as something completed; he did not reconstruct its history, but rather explicated "some 
of the concepts which together form the synthetic theory" (1959, p. 3). The concepts are: Mutation, population, natural selection, genetic drift, isolating mechanisms, geographic variation, gene and chromosome, species, higher categories. The theoretical status of the concepts and the structure of the Synthetic Theory are not discussed.

\section{Eldredge \& Gould 1972}

In their well-known paper "Punctuated Equilibria: An Alternative to Phyletic Gradualism" (1972) Eldredge and Gould write that "the modern synthesis received its name because it gathered under one theory - with population genetics at its core - the events in many subfields that had previously been explained by special theories unique to that discipline" (Eldredge \& Gould 1972, p. 108). As architects they mention Simpson, Dobzhansky, Mayr, de Beer, White, and Stebbins.

\section{Mayr \& Provine 1980}

The Evolutionary Synthesis by Mayr \& Provine (1980/1998) has become the central text for the discussion of the Synthesis. It is based on two conferences organized by Mayr in May and October 1974. (In contrast to the impression given in the book, Provine was not involved in the preparation of the conferences; pers. comm. by Ernst Mayr.) It highlights (1) the differences of opinion between Mayr and Provine, (2) the fact that many participants indicated that their own contribution had been unappreciated, (3) that some important authors did not want to participate, because their work was not represented correctly (e.g. Simpson and Stebbins; see Smocovitis 1996 for quotations from the unpublished correspondence between Simpson and Mayr), and (4) some authors were not invited (e. g. Wright). In the preface Mayr and Provine state that the Synthetic Theory was synthesized as a "seemingly [sic] new theory of evolution" between 1936 and 1947 and that the evolutionary synthesis was different in different countries (Mayr \& Provine 1980, p.xv, xvi). Both statements are not explained by the authors!

The long-lasting effect of the book - clearly aimed at by Mayr in his long introductory chapter - was to canonize the list-of-six-books (Dobzhansky 1937; Huxley 1942; Mayr 1942; Simpson 1944; Rensch 1947; Stebbins 1950) as the decisive basis of the Synthetic Theory and the view that the Synthesis was a most significant and rapid shift, which, however, did not involve a victory of one paradigm over another as in Kuhn's theory of scientific revolutions but rather an exchange of the most viable components of the previously competing research traditions of experimentalists and naturalists: "The evolutionary synthesis was a fusion of the widely different traditions" (Mayr 1980 a, p. 40). It was not "another revolution but simply the final implementation of the Darwinian revolution" (Mayr 
1980 a, p. 43; this view was strongly contradicted by Simpson; in Mayr 1980 c, p. 458).

Except for the statement of fusion and the mentioning of Laudan's (1977) models of "research traditions". Mayr did not use any philosophical models (e.g. Popper's "refutation of theories" or Lakatos" "research programs") to explain what type of event the Synthesis was. In contrast to Dobzhansky (see above) and Timoféeff-Ressovsky (see below) Mayr did not recognize a long-lasting research program towards a harmonized model of micro- and macroevolution that had spanned the $1930 \mathrm{~s}$ and $1940 \mathrm{~s}$. Rather he seemed to have had a rather sudden Gestalt-switch in mind which in the late $1930 \mathrm{~s}$ made the building of bridges between widely different research traditions possible: "The bridge builders [Dobzhansky etc.] were the real architects of the synthesis" (Mayr 1980a, p. 40).

Mayr's various historical reviews (1959, 1973, $1980 \mathrm{a}, \mathrm{b}, \mathrm{c}, 1982,1988$, 1992, 1993, 1996, 1998, 1999 a, b, see also below) of the events that lead to the Synthesis are not quite consistent because he did not distinguish between theoretical concepts of the authors and their practical research. In some contexts he worked only with publications that had a strong impact, in other contexts he mentioned publications that had no impact at all. Additionally it seems not sufficient to talk only about a fusion of research traditions as there were real losers and winners in all countries involved. (Among the losers were mutationist and Lamarckian geneticists, orthogenetic paleontologists, typological comparative morphologists and systematists etc.) Mayr did not mention Timoféeff-Ressovsky, Zimmermann, Heberer, Melchers, Reinig and Schmalhausen (see below).

Mayr's and Simpson's views of the Synthesis were almost exclusively influenced by their own experiences. They, especially Mayr, did not regard it as a long term project starting in the early $1930 \mathrm{~s}$, but rather as a Gestaltswith which was primarily caused by Dobzhansky 1937 (their - Simpson, Mayr's - own personal Gestalt-switches in the late 1930 s!). Mayr emphasized the (allopatric) speciation model as an indispensable part of the Synthetic Theory. Simpson, on the other hand, saw Mayr's species concept as counter-evolutionary and unproductive and emphasized his own evolutionary species concept as an essential part of the Synthetic Theory.

\section{Shapere 1980}

The philosopher Dudley Shapere summarized the discussion from his point of view: "Possibly the problems we face in defining the evolutionary synthesis result from an oversimplified way of looking at scientific innovation" (Shapere 1980, p. 388). Shapere pointed out numerous metatheoretical problems (what type of theory is the Synthetic Theory, what is its structure, how does in function, how do the various disciplines participate etc.?) and metahistorical problems (what type of process was the Syn- 
thesis, was it a scientific revolution, how were the various disciplines influenced by the Synthesis etc.?). Shapere saw three essential components of the Evolutionary Synthesis: (1) The reconciliation of Darwinian evolutionary theory and Mendelian genetics (this, however, is an accomplishment that we count as preparation of the Synthetic Theory - see below). (2) The introduction of new modes of thinking, e. g. populational thinking (attributed by Shapere to Dobzhansky 1937; the question is whether Dobzhansky only propagated these new modes of thinking that were already familiar in the respective scientific communities!). (3) The demonstration that the data of various other fields (paleontology, zoology etc.) were compatible with (1) and (2) (Shapere 1980, p. 398).

\section{Provine 1980}

In his epilogue to The Evolutionary Synthesis Provine also did not distinguish between preparation and formation of the Synthesis (see below) but listed 15 books (by Fisher, Wright, Ford, Haldane, Dobzhansky, Darlington, Huxley Mayr, Simpson, White, Rensch, Jepsen, Stebbins, Hardy, and Ford) from the years 1930 to 1954 as the major works of the Synthesis. Provine agreed neither with the more traditional view (expressed in some books on the history of genetics) that the formation of population genetics (around 1930) was the Synthesis nor with Mayr's view of a rapid bridge building but concluded: "The evolutionary synthesis was a very complex process; its historical development cannot be encompassed accurately by any single thesis. The synthesis occurred on many levels. [...] [It] was more than a simple application of new concepts in genetics to other facets of evolutionary biology, as earlier accounts have suggested" (Provine 1980, p. 405).

\section{The development in Germany}

The development in Germany is discussed in three short articles in The Evolutionary Synthesis. Mayr, Rensch and Viktor Hamburger concentrated mainly on the skepticism against selectionism in Germany. Mayr briefly mentioned Timoféeff-Ressovsky (as a person but not his work) and Gerhard Heberer's Die Evolution der Organismen, simply stating that no author of the book defended Lamarckian ideas and that all accepted a more or less selectionist interpretation. Mayr did not study the German literature in detail to find out how German biologists participated in the Synthesis. Rensch mentioned Timoféeff-Ressovsky, Zimmermann, Heberer, Fritz von Wettstein, Victor Franz and himself as authors who accepted a fully selectionistic view and who were willing to extrapolate from microevolution to macroevolution. All three articles were mainly written from memory. A careful analysis of German research traditions can not be found in them. In spite of these shortcomings it has to be emphasized that 
the international character of the Synthesis was recognized in Mayr \& Provine (1980). This, however, had not much effect, as some of the following quotations demonstrate.

\section{Eldredge 1982}

A extreme example of the hard historiographical version can be found in Niles Eldredge's preface to a reprint of Mayr's Systematics and the Origin of Species (1982). Eldredge claims that "three books form the nucleus of the synthesis: Dobzhansky's (1937) Genetics and the Origin of Species, Mayr's (1942) Systematics and the Origin of Species, and Simpson's (1944) Tempo and Mode in Evolution" (Eldredge 1982, p. XV). Although he admits that "these men and many colleagues probed and analyzed the details in hundreds of shorter contributions published in scientific journals" the books mentioned above are considered as the "the main organizing documents of the synthesis". They are the "fundamental statements of the synthesis" and this is the rational, why it is "by no means merely idle or simply convenient to focus" on them (Eldredge 1982, p. XV-XVI). In his argument Eldredge mentions one very important reason for the hardening of the historiography of the evolutionary synthesis: It is, of course, very 'convenient' to focus on few books rather than having to deal with various scattered publications in different languages. The international character of the Synthesis turned out to be a obstacle for a comprehensive historiographical account.

\section{Mayr 1982}

One of the few authors who frequently stressed the international character of the evolutionary synthesis was Ernst Mayr. In The Growth of Biological Thought he distinguished between (1) the six architects of the synthesis (Dobzhansky, Huxley, Mayr, Simpson, Rensch and Stebbins), (2) "numerous other evolutionists who had helped to "clear the terrain" (i.a. Chetverikov and Timoféeff-Ressovsky in the USSR [sic], Baur, Ludwig, Stresemann and Zimmermann in Germany) and (3) "two multiauthor volumes have also contributed to the synthesis: Heberer's edited volume, Die Evolution der Organismen (1943a) and Julian Huxley's The New Systematics (1940)" (1982, p. 568).

\section{Mayr 1988}

Mayr's (1988) essay on the Synthesis in his Toward a New Philosophy of Biology has several interesting aspects: (1) Mayr criticized Rensch strongly for not representing the German Synthesis adequately in his contribution to Mayr \& Provine (1980/1998). This is especially true for E. Baur and Timoféeff-Ressovsky. (2) "The period of the synthesis was not one of great 
innovations but rather of mutual education" (Mayr 1988, p. 525). This gives a new twist to the discussion of the Synthesis! (3) Mayr emphasized that many new aspects were added to the Synthetic Theory after the Synthesis. These additions were easily accommodated by the Synthetic Theory and they do not refute it.

\section{Provine 1988}

In 1988 Provine emphasized that it is hard to determine what exactly constituted the Synthesis. It is, however, obvious for him that during the historical process theoretical assumptions such as Lamarckism, saltationism/ mutationism, directed evolution, teleological causes etc. were eliminated. Provine suggested that instead of a synthesis a "constriction" had taken place:

“The term 'evolutionary constriction' helps us to understand that evolutionists after 1930 might disagree intensely with each other about effective population size, population structure, random genetic drift, levels of heterozygosity, mutation rates, migration rates, etc., but all could agree that these variables were or could be important in evolution in nature, and that purposive forces played no role at all. So the agreement was on the set of variables, and the disagreement concerned differences in evaluating relative influences of the agreed-upon variables" (Provine 1988, p. 61).

\section{Smocovitis 1992}

In recent years Betty Smocovitis has presented a hard version of the Synthesis. She claimed that "the evolutionary synthesis was primarily an American (to some extent, an Anglo-American) phenomenon". Her argument in favor of this view is circumstantial: The Synthetic Theory was strongly selectionistic and the belief in selection was "offering a sense of progress, a liberal ideology, and an optimistic and coherent worldview with humans as the agents of their own evolution". Since "the sense of easy progress and optimism that characterized postwar American culture was not mirrored by the war-torn continent" there was no Synthesis on the (European) continent (1992, p. 40 n.).

\section{Mayr 1993}

In 1993 Mayr reviewed Smocovitis' (1992) paper and summarized the status of the Synthetic Theory. He regarded the Synthesis as the final implementation of Darwin's theory. This accomplishment that spanned almost 80 years was an absolutely unique scientific revolution for him. Mayr repeated the list-of-six-books (Dobzhansky, Huxley, Mayr, Simpson, Rensch and Stebbins). The Synthesis "was rather more than a synthesis" (Mayr 
1993, p. 31): it was a refutation of antidarwinian paradigms, a synthesis of the thinking of three major biological disciplines (genetics, systematics and paleontology), a synthesis between experimental and naturalist philosophy and a synthesis between the Anglophone tradition with its emphasis on mathematics and adaptation and the continental European tradition with its emphasis on populations, species and higher categories.

Mayr stated that by 1950 the integration of the disciplines was not yet fully completed and that it continued until the present and that historians, "perhaps even Mayr and Provine, have overemphasized the unity achieved by the synthesis" (Mayr 1993, p. 32). Mayr elaborated neither on the content nor on the structure of the Synthetic Theory but stated that it can still be expanded and that it could accommodate newly discovered principles as long as they do not disagree with the basic Darwinian structure of the Synthetic Theory.

\section{Mayr 1996}

Mayr's Capstone Address, presented at the $75^{\text {th }}$ Annual Meeting of the American Society of Mammalogists (Mayr 1996) does not deviate from the preceding article but is remarkable for its emphasis of the "incredible rapidity" (Mayr 1996, p. 1) with which the Synthesis was accomplished after 1937.

\section{Smocovitis 1996}

In her latest book Smocovitis has answered to the criticism (e. g. by Mayr 1993) of nationalistic bias by mentioning that "the United States became a center for scientific research immediately following the Second World War” (1996, p. 207). Although this is certainly true, it is no justification for the exclusion of other national contexts of activity in evolutionary biology before 1945, because - even according to Smocovitis - the Evolutionary Synthesis "took place between the third and fourth decades of the twentieth century during the interwar period" (1996, p. 7). The international character of the Synthesis is only seen as a 'complication' leading into different directions:

"Further complicating historical understanding were the national contexts for evolutionary activity represented at the workshop [Mayr \& Provine 1980]. Nations as different as the Soviet Union, Germany, France, England, and the United States held to their respective contributions and historical interpretations. Historical exploration of the national contexts of activity made it apparent that the synthesis appeared to take radically different historical directions in different national contexts” (1996, p. 33).

Smocovitis concludes with the following statement which is difficult to accept: Her own view of the Synthesis "does stress Anglophone contribu- 
tors, possibly to the exclusion of other national contexts of evolutionary activity. Here I wish to respond with an affirmative answer to the wellworn question of whether the synthesis was an Anglo-American event; I would also add that such an assertion in no way excludes [?] the contributions of other national contexts of activity" (1996, p. 207).

The irony is that not the history but the historiography of the Synthesis has been an "Anglo-American event". However, if one sees the Synthesis as an international research program of geneticists, population biologists, biogeographers, systematists, botanists, comparative animal morphologists and (some) paleontologists spanning the $1930 \mathrm{~s}$ and $1940 \mathrm{~s}$ it is no longer an "Anglo-American event" and many of the historiographical and philosophical problems disappear.

\section{Ruse 1996}

A similar argument as Smocovitis' can be found in Michael Ruse's Monad to Man (1996). Since "Anglo-American evolutionism is the biggest, the best, the most mature" and the "work in these two countries since Darwin is the most direct route to the present" any discussion of other countries is excluded, "except inasmuch as it impinges on British and American evolutionism" (Ruse 1996, p. 178). It is the question whether Ruse reads German at all (see our chapter VIII on the language barriers) and whether he felt at all uneasy to neglect the notorious German evolutionary progressionism of the nineteenth and twentieth century in a book devoted to “The Concept of Progress in Evolutionary Biology" (subtitle).

\section{Junker \& Engels 1999}

In 1999 Thomas Junker and Eve-Marie Engels published the contributions to a symposium that was devoted to the Synthesis in Germany ${ }^{1}$. The authors in this book discuss a whole series of German biologists (see ch. VII) who made significant contributions to the Synthesis, but most importantly several authors (e.g. Haffer and Reif) show that according to the German literature (1) an empirical analysis of the evolutionary factors (in the laboratory and in natural populations), (2) a reconciliation of the various disciplines toward a coherent model of microevolution and (if possible) a coherent model of macroevolution had been on the agenda of several geneticists, population biogeographers and morphologists since the early 1930s, and (3) that the German translation (1939) of Dobzhansky

\footnotetext{
${ }^{1}$ In two subsequent conferences (Göttingen 1997 - organized by Rainer Brömer, Uwe Hoßfeld and Nicolaas A. Rupke; Regensburg 1999 - organized by R. Brömer and U. Hoßfeld) the questions presented at the Tübingen Workshop (December 1996) were further discussed from different perspectives (see Brömer; Hoßfeld \& Rupke 2000; Hoßfeld $\&$ Brömer, in prep. July 2000). Together these three workshops document the growing interest in the history of European evolutionary biology.
} 
(1937) did not cause any surprise among the leading German evolutionary biologists. However, it cannot be denied that except for Ludwig and Pätau there were hardly any competent theoretical population geneticists and that Germany had no Simpson (for Schindewolf, one of the leading German paleontologists between 1930 and 1965, see Schindewolf 1936, 1950 and Reif 1983, 1986, 1993, 1997, 1999 a, b).

Mayr claims that the process in Germany was started by the German translation of Dobzhansky's book, which was "as much a cornerstone of the German Synthesis as it had been of the American one" (Mayr 1999a, p. 22; similar Hoßfeld 1998 a). Reif (see also Reif 1983, 2000 a) contradicts this view by stating that (some) German biologists were involved in an international research program towards a synthesis since the early $1930 \mathrm{~s}$. These statements about the origin and meaning of the Evolutionary Synthesis demonstrate that no general agreement has been achieved. Before we can speak about contributions of German biologists to this Synthesis, it is therefore necessary to develop criteria for the identification of the authors. The next two chapters will suggest an approach.

\section{Functional Criteria for a Synthesis}

Before an answer to the German contribution to Synthesis can be given it is necessary to address some theoretical, metatheoretical and historiographical issues. What was the Synthesis as a historical process? Was it (1) a fusion of the research tradition of disciplines or (2) a narrowing of the focus to a limited number of evolutionary factors and a gradual rejection of factors that turned out to be incompatible with the Darwinian framework of the theory. What type of theory dynamics did the origin of the Synthetic Theory represent - was it a paradigm shift, a scientific revolution? What is the content of the Synthetic Theory? What kind of a theory is the Synthetic Theory? Has it changed since it was first formulated? Has it (i. e. the theory itself) "hardened", i. e. was its pluralism reduced? How did the historiography of the Synthesis develop? Has it (i. e. the historiography) "hardened", i. e. did it reduce its pluralistic stance toward the number of the contributors ("architects") of the Synthesis?

In order to call any modern theory of evolution a "Synthetic Theory" several criteria have to be met (Reif 1999a): a) It has to be shown that all biological disciplines involved in evolutionary biology (systematics, ecology, paleontology, genetics, developmental biology, biogeography etc.) developed a set of theorems that are not contradictory and that suffice for describing the mechanisms of evolution. b) It has to be shown that unsolved problem of one discipline become solvable through a cooperation with another discipline. c) The Synthetic Theory must be able to produce new research projects by a cooperation of different biological disciplines. 
Most students of the Theory of Evolution will agree that all three criteria are largely met by the Synthetic Theory. Criterion (a) is still heavily discussed. Criterion (b) is almost universally accepted. Criterion (c) is acceptable; however, detailed documentations of new evolutionary research programs that were based on the Synthesis and were implemented after 1950 in the various countries involved (U.K., USA, Germany USSR, Italy etc.) would be required.

Shapere (1980) outlined two criteria for a synthesis: (1) All data of each of the scientific areas in question must be logically deducible from a relatively few basic ideas of a synthesized Darwinian-Mendelian theory. Shapere stated that this view of completeness is much too stringent (p. 388). (2) A set of data can be understood in the light of a new theory that also allows new questions to be asked. (For example, it could be said that a new understanding of paleontological data was gained in the light of Darwinism-Mendelism and new questions were made possible (p. 389).

\section{Structure of the Synthetic Theory}

In order to find out whether an author of the $1930 \mathrm{~s}$ and $1940 \mathrm{~s}$ can be said to have contributed to the Synthesis or whether a modern author can be regarded as an adherent or an opponent of the Synthetic Theory it is necessary to develop criteria for the identification of the Synthetic Theory. This is a very difficult task as it is connected with numerous theoretical and metatheoretical (philosophical) problems (Reif in prep.):

a) The claim of an author that he fully agrees with the Synthetic Theory can not be always regarded as reliable. Some authors say that they agree with the Synthetic Theory, but they seem not know it to a sufficient degree. Hence it is necessary to study all theoretical propositions of all authors in detail.

b) The discussion in the literature of what kind of a theory the Theory of Evolution is (in comparison to a theory in physics) has led to no conclusion so far (Burian 1988; Wassermann 1978, 1981). Can it make predictions, and - if not - why not? Can it be refuted? Are there evolutionary laws? Is the Theory of Evolution a deterministic or a probabilistic theory? What is the status of macroevolution (given the fact that there are no specific macroevolutionary factors or laws? (See Williams 1970, $1973 \mathrm{a}, \mathrm{b}$, 1981; Munson 1975: Caplan 1978; Olding 1978; Ayala 1982, 1983; Horan 1994; Ariew 1998).

c) The attempt to axiomatize the Theory of Evolution (Williams 1970; for discussion see Ruse 1971, 1973) has lead to no satisfactory results. Like all biology evolutionary theory has a strong historical ("narrative") component (Journet 1995). 
d) The multi-level model (Tuomi 1981, 1992) and the semantic model (Beatty 1987; Suppe 1977, 1979, 1988; Lloyd 1988; Thompson 1980, $1983 \mathrm{a}, \mathrm{b}, 1987,1988)$ of the evolutionary theory do not readily allow the detailed comparison of the theories of individual authors (Reif in prep.).

e) The fact that the metatheoretical aspects of the Theory of Evolution have not been clarified has lead to an ongoing discussion of whether proposals such as the Neutral Theory of Evolution (Kimura 1983), the hypothesis of Punctuated Equilibria (Eldredge \& Gould 1972; Gould \& Eldredge 1977), the hypothesis of Species Selection (Stanley 1979), the model of a hierarchical structure of evolution (Eldredge 1979, 1985; Gould 1981, 1982 a, b, 1995; Stanley 1979; Vrba \& Eldredge 1984), the hypothesis of mutualism and group selection (Wilson 1992; Sober \& Wilson 1998) etc. have to be regarded as refinements, marginal additions, expansions or refutations of the Theory of Evolution (Smith 1979; Levinton \& Simon 1980; Grant 1983, 1985; Sober 1984; Darden 1986; Stebbins \& Ayala 1985; Hecht \& Hoffman 1986; Mayr 1988; Levinton 1988; Hoffman 1989; Burian 1988; Gayon 1990; Grene 1990; Ridley 1993, 1997; Fitch \& Ayala 1995; Sepkoski 1996).

f) There is no agreement in the literature of whether hypotheses such as Punctuated Equilibria, Species Selection and Group Selection have a sufficient conceptual and empirical basis to accept them at all and regard them as serious candidates for an expansion or refutation of the Synthetic Theory (Reif 2000 b). We do not accept here Gould's claim that the Synthetic Theory is "effectively dead" (Gould 1980 a, p. 120).

The attempt to define the Synthetic Theory of Evolution by simply listing those theoretical claims on which all or most architects (Dobzhansky, Huxley, Mayr, Simpson, Rensch and Stebbins) of the theory agreed would be circular: First one bases the content of the Synthetic Theory on a list of the architects and then one tries to find criteria of who was an architect from a presupposed description of the Synthetic Theory (see Gayon 1990). In addition the metatheoretical problems of the Synthetic Theory would be neglected. The purpose of a characterization of the Synthetic Theory is to provide a working basis for theorists of biology, for historians of science and for philosophers of science (who deal with metatheoretical problems). It is necessary to characterize the Synthetic Theory not too narrowly (this could lead to the result that every author has his own theory) and not too widely, in order to be able to distinguish the Synthetic Theory from other theories of evolution.

We propose here a structuralistic concept of the Synthetic Theory (Reif in prep.). We found that an axiomatization or a semantic model or a hierarchical model do not lead to a workable definition of the Synthetic Theory. The components (evolutionary factors etc.) of the theory are mutually interdependent (hence the notion of structuralism). It is not the case that the evolutionary factors are autonomous theories that are combined to inter- 
field theories. Rather the factors signify working programs (with their own theoretical backgrounds, to be sure) but they make evolutionary sense only in combination. One simply does not study mutation or isolation per se. If an author regards selection as the single most important component of the theory (and thus rejects random effects such as drift and neutral mutations practically completely) this has necessarily implication for the whole theory. The same is true for any other component: gradualism versus saltationism, selection restricted to the individual level versus selection taking place from the gene level to the species level etc. By implication, the structuralistic approach rejects the assumption that the Synthetic Theory can be derived from first principles (i.e. can be axiomatized) or is a reductionistic theory.

A structuralistic model of the Theory of Evolution has several advantages: 1) It reveals metaphysical and methodological connotations of an author that he may not even be aware of. 2) Terminological confusions can be avoided to a significant degree because the terms are clarified with respect to their function in the rational framework of the theory. 3) It is possible to demonstrate the deviations of a theory of a certain author from a logical, contingent, consistent and rational structure. 4) Authors may not debate all aspects of their theory. However, a structuralist analysis can demonstrate that an author held an inherently teleological view, though he may not be aware of it or may flatly reject such a charge.

From a structuralistic point of view, the Synthetic Theory can easily integrate additions and refinements. However, we will not tackle the problem which kind of theoretical proposals would refute the Synthetic Theory (see Williams $1973 \mathrm{a}, \mathrm{b}$ ). The structuralistic description of the Synthetic Theory that we use is based on: 1) The concepts of those authors of the 1930 s who worked towards the Synthesis. 2) The results of authors that carried out the Synthesis. 3) The research programs of authors who worked successfully on the basis of the Synthesis.

The essential five components of the Synthetic Theory are:

- Mutations (that are random with respect to the adaptive needs of the organism).

- Selection (restricted largely to the level of the individual) as the main directing force of evolution (see Arnold \& Fristrup 1982; Arnold \& Wade 1984; Beatty 1980; Brandon 1981, 1982, 1986, 1990; Brandon \& Burian 1984; Craig 1982; Franklin \& Lewontin 1970; Lewontin 1970, 1972, 1978; Muller 1949).

- Recombination in sexually reproducing populations.

- Isolation (prevention of gene flow due to geographic or ecological separation, and pre-mating or post-mating genetically determined isolating mechanisms).

- Drift (random loss of genes from the gene pool in small populations or in populations whose size or geographic distribution changes rapidly). 
Several other relevant components follow automatically from this basic structure:

- Speciation is predominantly allopatric or parapatric. Sympatric speciation requires special ecological mechanisms or random events.

- Evolution is gradual, but can have a wide spectrum of velocities.

- Macroevolution, i. e. the origin of higher taxa, adaptive radiations, adaptive shifts of higher taxa etc. is gradual and does not require special mechanisms (e. g. Bock 1979; Dudley 1991).

- Developmental, historical and constructional constraints limit the opportunism of evolution to a certain degree, but do not lead to non-adaptive evolution (Alberch 1982, 1985; Amundson 1984; Arnold 1992; Atkinson 1992; Barel et al. 1989; Bjorklund 1996; Boletzky 1997; Carter et al. 1992; Futuyma 1986; Hecht \& Hoffman 1986; Levinton 1986; Reif et al. 1985; Resnik 1995; Schwenk 1995; Skelton 1993; Smith et al. 1985; Strathman 1975; Wagner \& Misof 1993; Wimsatt 1986).

The Synthetic Theory rejects:

1) Concepts refuted by many geneticists:

- Macromutations ("systemic mutations", as claimed by Goldschmidt 1927, 1935, 1940; see Goldschmidt 1959, Diedrich 1995 and Piternick 1980 for further information)

- Lamarckian inheritance and Geoffroyan mechanisms

2) Macroevolutionary notions:

- Progressive evolution as an inherent trend

- Teleology (goal oriented evolution)

- Cyclic evolution (evolution of higher taxa in strict analogy to the life cycle of an individual: rapid youthful origin, stable adult phase, deteriorating old age)

- The autonomous evolution and unfolding of higher taxa

- Orthogenesis (rectilinear evolution = "orthogenesis A" and internally driven evolution $=$ "orthogenesis B")

- Autogenesis $=$ autonomous evolution of taxa without interaction with the environment

- "Racial senescence" = ageing of the genome

- "Baupläne" or types as actors in evolution

- Saltations: jumps from an ancestral taxon to a descendant taxon

Several historians and theorists have pointed out that the five factors (mutations, recombination, selection, isolation and drift) were already known by the theoretical population geneticists. Beatty (1986; see also Bechtel 1986) emphasizes that this is true, but that it was the major contribution of the architects of the Synthesis (especially Dobzhansky) to carry out laboratory and field studies in order to determine the relative strengths of 
the five factors. Beatty's argument points to the importance of experiments and field studies in the descriptive sciences (natural history) (see Sober 1993; Rheinberger 1997; Reif 1999 b). It is necessary however, to emphasize - in addition to Beatty (1986) - that there are two more accomplishments of the Synthesis: a) Factors other than mutation, recombination, selection, isolation and drift were excluded, and b) it was demonstrated by extrapolation that the factors acted in macroevolution in the same way as in microevolution.

\section{The Four Phases in the Historical Development of the Syn- thetic Theory}

In order to clarify the criteria of whether an author contributed to the development of the Synthetic Theory or not it is not only necessary to characterize the Synthetic Theory and compare the theory of a certain author with this characterization. It is also necessary to distinguish historical phases in the development of the Synthetic Theory. We use the following classification here (from Reif 1998; see Cain 1992 for a slightly different historical grouping):

1) "Roots": This covers the time up to around 1920. This phase is characterized mainly by a clarification of the laws of inheritance (Johannsen), the discovery of the chromosome theory of inheritance (Boveri, Morgan, Muller), the discussion between micro- and macromutationists (de Vries, Johannsen, Bateson, Pearson). In systematic biology, comparative morphology, developmental biology, biogeography and paleontology it is more difficult - given our current knowledge of history of biology - to point out developments in these disciplines that can be regarded as research projects leading to eventually to a synthesis (see Haffer 1997).

2) "Preparation": This period covers especially the second half of the $1920 \mathrm{~s}$ and the first half of the $1930 \mathrm{~s}$. The most important developments were: mathematical population genetics (Fisher, Wright, Haldane, Chetverikov, Pätau, Ludwig, Gause); field studies and experimental studies of populations (Chetverikov, Dubinin, Dobzhansky, Timoféeff-Ressovsky, Erwin Baur, Reinig, I. I. Schmalhausen, A. S. Serebrovskij, A. N. \& S. N. Sewertzoff, V. N. Sukacev); developmental genetics (Goldschmidt, Kühn); a first attempt of a paleontologist to clarify the discrepancies between genetics and paleontology (Schindewolf 1936; this attempt failed, see Reif 1997, 1999 a); biogeography of species and other lower taxonomic units (races, ring-species, polytypic species; Rensch, Stresemann, Mayr); small-scale evolution and statistical analysis in the fossil record (Rudolf Kauffman, Rudolf Wedekind; see Hoffman \& Reif 1984). 
3) "Formation" of the Evolutionary Synthesis (1930s and $1940 \mathrm{~s}$ - according to many authors 1937 to 1950). As noted in chapter (V) the Synthesis made the following contributions: Empirical analysis of the relative strength of the five evolutionary factors (mutation, recombination, selection, isolation and drift) that resulted from theoretical population genetics; theoretical and empirical exclusion of other evolutionary factors; extrapolation from microevolution to macroevolution; clarification of the origin of diversity and speciation (Hoßfeld, Junker \& Kolchinsky 2000).

4) "Reception" of the Synthetic Theory of Evolution (1950 to the present). The Synthetic Theory gained wide acceptance already in the late 1940 s and in the 1950 s. This statement must be modified in four ways: a) By no means all authors of the late $1940 \mathrm{~s}$ and the $1950 \mathrm{~s}$ used the term 'Synthetic Theory' (see above). The term is especially missing in the three major Festschriften commemorating the 100. Anniversary of Darwin's Origin of Species (Tax 1960; Barnett 1962; Leeper 1962; Mayr 1962; see Reif $2000 \mathrm{a}$ ). The acceptance of the terms 'Evolutionary Synthesis' and 'Synthetic Theory' is largely due to the many theoretical and historical publications by Simpson and Mayr. b) Not all evolutionary biologists who had actively done research between 1930 and 1960 considered the time between 1937 and 1950 as an extraordinary period (see chapter VII). c) The acceptance of the Synthetic Theory after World War II was much stronger in the Anglo-american countries than in Germany (Reif 2000 a), France, the Soviet Union etc. d) There is still a wide discrepancy among theorists not only as to what kind of a theory the Synthetic Theory is but also what type of process lead to the Synthetic Theory.

According to Gould (1983 a, b) the first formulation of the Synthetic Theory was more pluralistic than its later developments. According to his historical analysis later versions of the Synthetic Theory were stronger dogmatic with respect to their exclusive emphasis of selection than earlier versions. Mayr, on the other hand, emphasized that the selection-antiselectionist trend was exactly the opposite in 1930 s (1988, pp. 528-529). Antonovics, agreeing with Gould, went so far as to state: "The Synthesis placed restrictive notions on the conceptual richness and depth of evolutionary biology as a science" (1987, p. 326). A careful analysis as to how the Synthetic Theory changed the research programs of the various disciplines after 1950 is still missing. The accepted version of the Synthetic Theory was challenged from several sides (paleontology, genetics, selection theory etc.). Theorists and philosophers who reacted to these challenges have seen no need to modify the Synthetic Theory (Burian 1988; Grene 1990; Grant 1983; Hecht \& Hoffman 1986). A detailed theoretical and historical analysis of the time period of 1970 to the present is still missing. The account of Smocovitis (1996) is anecdotal and not systematic. 


\section{German Contributions to the Synthesis}

What were the contributions of biologists living and working in Germany to the Synthesis? In this section we will give a preliminary answer to this question by discussing the work and theories of some of the candidates for such a contribution. Our account will be far from complete and it will include some authors who were part of the scientific environment of the Synthesis, but did not add any original work. We use 'German' in the sense of language and geography, and not in the sense of German scientific traditions. I. e. we include the work of Timoféeff-Ressovsky, who lived and published in Germany, but not that of Ernst Mayr, who was strongly influenced by his German background, but had emigrated to the USA. Our arrangement of the authors is roughly chronological in order to pick up our distinction between roots, preparation, formation, and reception of the Synthesis.

\section{Erwin Baur (1919, 1925, 1932)}

Erwin Baur was certainly one of the most important architects of the Synthesis. His early death (1933) prevented him from playing a major part in the actual formation of the Synthesis, but his work made him a central figure of the preparatory phase: "If he had lived, he would probably be recognized now as one of the fathers of the synthetic theory of evolution in plants" (Stebbins 1980, p. 140). Baur's very popular genetics textbook Einfübrung in die experimentelle Vererbungslebre was probably one of the most influential publications that prepared the ground for the Synthesis in Germany. As early as 1919 (3rd/4th. ed.) Baur presented an evolutionary theory that was based on a synthesis of genetics, the theory of selection and a basic idea of population genetics. He was convinced that the quantity and diversity of mutations in nature is sufficient to guaranty an efficient process of selection (Baur 1919, p. 343). On the other hand, he had some doubts whether this microevolutionary mechanism is sufficient to explain macroevolution and speculated that new types of mutations might be found (Baur 1919, p. 345).

In 1925 Baur presented his most important synthetic ideas in a short paper on the meaning and importance of mutations for evolution ("Die Bedeutung der Mutation für das Evolutionsproblem"). Here he emphasized that differences between closely related species can be explained by the accumulation of (micro-)mutations (see also Baur 1924; Mayr \& Provine 1980; Harwood 1993). He demonstrated that in natural populations sufficient genetic polymorphism (resulting from random mutations and recombination) for selection to act is present. Baur had no clear notion yet of gene pools, gene flow and genetic isolation but he emphasized that the (at that time dominant) criticism of selection was unproductive. Baur clearly rejected Lamarckian inheritance. 
In a paper of 1932 he gave a short documentation of his genetic studies of the garden snapdragon Antirrbinum and of his extensive studies of natural populations of Antirrbinum section Antirrbinastrum in southwest Europe. This was one of the first empirical studies of population biology which took all relevant aspects into account such as genetic variation, hybridization of populations, spatial and genetic isolation, and hybrid viability. Baur's work clearly aimed at a synthesis between genetics and the theory of selection and through his analysis of natural populations of Antirrbinum he pioneered the "Back-to-Nature" movement that later became an earmark of the Synthesis.

\section{Max Hartmann (1927, 1939)}

Evolutionary theory played a comparatively small role in the influential text-book Allgemeine Biologie by the geneticist Max Hartmann (10 pages out of 750; 2d ed. 1933). It first appeared in 1927 and went through several editions. Hartmann started from the assumption that the theory of descent is based on the natural classification which itself uses typological similarities on all taxonomic levels. He gave a range of evidence that proves beyond any reasonable doubt that the theory of descent is true. Experimental genetics and other considerations have indicated that Lamarckian inheritance must probably be rejected (Hartmann leaves some room for Lamarckian inheritance through Dauermodifikationen; Hartmann 1933, pp. 655-656). On the other hand it has turned out that micromutations are much more common in natural populations than had hitherto be assumed. Hence random (micro-)mutations, recombinations and Darwinian selection must be the main factors of evolution.

Hartmann was not convinced, however, that "for the time being" random micromutation can be regarded as a sufficient explanation for complex adaptations and (orthogenetic) trends. Hartmann speculated that these macroevolutionary phenomena might be caused by directed mutation pressure under extreme conditions (Hartmann 1933, p. 658). Although the reader finds no understanding that species are reproductive communities and despite his speculations about a significant role of directed mutations, Hartmann's text-book is an important statement of some basic genetic notions of the Synthesis during its preparation phase.

Hartmann's preface to the German translation of Dobzhansky's Genetics and the Origin of Species indicates that he was aware of the scope and content of the Synthesis during is formation phase as well. In different countries (he mentions Germany, Russia, and America) geneticists are working on a new synthetic synopsis ("einer neuen synthetischen Zusammenfassung") of genetics, cytology, biogeography, mathematical analysis. Hartmann saw Dobzhansky's book as a summarizing account of these attempts (Hartmann 1939, p. III-IV; see Harwood 1993, p. 44-45). 


\section{Nikolai W. Timoféeff-Ressovsky (1927, 1937, 1939, 1940, 1943)}

Timoféeff-Ressovsky was an important representative of the international Synthesis and the central figure of the (microevolutionary) Synthesis in Germany (see also Glass 1990; Voroncov 1993; Hoßfeld 1998 a, 1998 b; Junker $1998 \mathrm{~b}$ ). He had studied genetic variability in natural populations of Drosophila as early as 1927 (H. A. \& N. W. Timoféeff-Ressovsky 1927; more references to his early publications can be found in Timoféeff-Ressovsky $1939 \mathrm{a}, \mathrm{b}$ ). This is quite remarkable because this project was carried out not after but during the forming years of theoretical population genetics and earlier than most of Dobzhansky's studies of natural populations. From that time on Timofeeff-Ressovsky worked towards empirical tests of the relative importance of the evolutionary factors (clearly a research program of the Synthesis). The importance of Timoféeff-Ressovsky's work was appreciated by the other architects of the Synthesis, especially by Dobzhansky. In Genetics and the Origin of Species numerous references to Timoféeff's publications can be found. Dobzhansky particularly emphasized the following results and experiments: 1) The effect of a mutation on viability depends on both the environmental conditions and the genetic structure of the organism; 2) Basic experiments to determine the relative frequency of the different types of mutations; 3) Timofeeff's demonstration that mutations producing small changes in the phenotype occur at a high frequency; 4) One of the first systematic studies on the occurrence of mutations in wild populations of Drosophila melanogaster (Dobzhansky 1937, pp. 20, 24, 26, 41).

"Genetik und Evolution" (1939a) is one of the most important review articles of Timoféeff-Ressovsky (Hoßfeld $1998 \mathrm{a}$ ). Central is a discussion of the relative importance of the factors of evolution on the basis of theoretical population genetics and empirical population studies. Most interesting are his definitions of population and of species (genetically isolated, freely interbreeding populations). He also discusses the importance of genetic constraints for the variability of a population (p. 189). Timoféeff-Ressovsky left no doubt that macroevolution is under control of the same factors as microevolution. He did not discuss patterns of macroevolution but limited himself (exactly as in his contribution to Heberer's book, see Bauer \& Timoféeff-Ressovsky 1943; Reif 1999 a) to the topics and results of empirical and theoretical population genetics and cytogenetics.

In 1969 Timofeeff-Ressovsky published a short text-book on the theory of evolution together with N. N. Voroncov and A. V. Jablokov (German translation 1975). The authors did not accept the American historiography of the Synthesis in their short historical review of $1 \frac{1}{2}$ pages. Rather they called the development of theoretical population dynamics and the first studies of genetics in domestic plants (Vavilov, Fisher, Wright, Haldane, Dubinin, Romasov) a "long and difficult starting phase of the synthesis of 
genetics and Darwinism" (1975, p. 66). This was followed by "the passionate development of modern evolutionary theory. The synthesis of genetics, systematics, biogeography and ecology resulted in the theory of microevolution" (1975, p. 66). The only publications mentioned here are Dobzhansky (1937) and Timoféeff-Ressovsky (1939a, b, 1940). The authors regarded macroevolution as a different research tradition which required not only comparative morphology, paleontology and embryology, but also genetics, ecology, biochemistry and molecular biology for the solution of its problems. The relevant authors who are mentioned here are Huxley, Schmalhausen, Mayr, Rensch Simpson, Takhtajan "and many others" (1975, p. 66).

Timoféeff-Ressovsky's historical review reflects his own working program during his time in Germany (1925-1945): The fundamental paper of Chetverikov (1926; which, incidentally, was partly translated and published by Dobzhansky in his paper of 1959) marked the beginning of theoretical and empirical population genetics and formed the basis of a working program towards a reconciliation of genetics and the Theory of Evolution and eventually towards a model of microevolution (that was free of inner contradictions; see also Adams 1967, 1970, 1980 a, b). Timoféeff-Ressovsky probably never doubted that this would also solve the problem of macroevolution but never made macroevolution a part of his research program. The harmonized models of micro- and macroevolution would then form the basis for an expanded evolutionary research program. In other words Timoféeff-Ressovsky did not see the modern theory of evolution (in 1969/1975) as a new paradigm but rather as a complex of theoretical and empirical insights towards which he had worked at least since the early $1930 \mathrm{~s}$.

\section{Walter Zimmermann (1928, 1930, 1943)}

Zimmermann's first paper of evolutionary importance was an article of 1928 that emphasized the ubiquity of adaptive characters in plants and sexuality as a highly adaptive feature. Zimmermann's main concern was methodology, i. e. the possibility of arguing for or against (past or current) adaptations. Adaptation requires a directing factor in evolution, but for the sake methodological clarity Zimmermann left the nature of the directing factor (Darwinian selection or Lamarckian inheritance) open in the present context. (The reader has hardly any doubt that Zimmermann favored Darwinian selection.) It is remarkable, however, that Zimmermann (1928), in contrast to Darwin, did not attribute adaptive significance to differences between individuals within populations!

In his first book (Phylogenie der Pflanzen, 1930) Zimmermann argued strongly against (irrational) typology and idealistic morphology. Zimmermann emphasized that there is no empirical or general biological basis to 
accept macromutations as a mechanism for macroevolution, in other words, he argued strongly for gradualism and against special macroevolutionary laws. Evolutionary patterns, including extinction, are adaptive. Evolutionary irreversibility is very likely to occur simply because of the complexity of mutations. Haeckel's Biogenetic "Law" cannot be accepted as an evolutionary law. Evolution is always gradual and mainly caused by micro-mutations. Morphological gaps between higher taxa were caused by extinction. Evolutionary rates are controlled by the ecological situations and by mutation rates. (Zimmermann did not exclude a weak internalism here!)

With a careful analysis of empirical data and theoretical arguments Zimmermann rejected Lamarckian mechanisms. His question whether mutations in a non-changing environment would cause evolutionary processes or a evolutionary stand-still (p. 408) was much later taken up by Van Valen's Red Queen hypothesis (see Hoffman 1989). On the basis of calculations by Haldane Zimmermann emphasized the selective importance of even minute individual differences in populations. Evolution of higher taxa is caused by the accumulation of minute evolutionary stages (p. 411). Velocities of microevolutionary processes are high enough for the evolutionary origin of higher taxa within reasonable geological time spans (p. 414). Mutations are random; genetic factors (genetic constraints in modern terminology) lead to parallelisms. Selection is the center of Darwinism (p. 417). Speciation is prevented by gene-flow and is made possible by geographic isolation (p. 417). Vicariant local races are caused by mutations and are adaptations to local conditions; they can hybridize (p. 418). Geographic isolation leads to endemisms (p. 418). Differences between species are not necessarily adaptive (p. 418).

In a public lecture of 1934 at the University of Tübingen that has hardly been recognized by the German, let alone the international, historiography Zimmermann gave a short review and lucid argumentation in favor of his adaptationistic, selectionistic and gradualistic theory that emphasized that there is no difference between micro- and macroevolution, that Lamarckism cannot be accepted and that species are differentiated into local adaptive races. (Allopatric speciation by geographic isolation was not dealt with by Zimmermann 1934 a.)

It is difficult to imagine what aspects that were later developed by the synthesists are missing in Zimmermann's evolutionary theory of 1930! Zimmermann's 1938 book is a long explication of this theory. It is not important in the present context to analyze this book and his article of 1943 (see Reif 1999 a; Junker in print a) and it is impossible to analyze the reasons why it had a comparatively small influence on the German scientific community of evolutionary biologists and why it was not read by the international audience of theorists and historians before or after World War II. Simpson (1949b) in his review of Zimmermann 1949 emphasized that 
he did not know Zimmermann's earlier work! One reason for the poor reception of the book of 1938 could be its misleading title. Vererbung 'erworbener Eigenschaften' und Auslese (Inheritance of 'Acquired Characters' and Natural Selection) sounds like a defense of Lamarckism. What is meant in reality is the acquisition of new characters by genetic (Darwinian) mechanisms and their inheritance and selection.

After the war Zimmermann wrote several books on phylogeny, evolution, epistemology, philosophy of biology and the history of evolutionary theories. Zimmermann did not regard Dobzhansky's book of 1937/1939 as a major breakthrough. Despite his being well-informed about the modern American literature after World War II he never took up the idea of an Evolutionary Synthesis, or of a radical renovation of evolutionary thought starting with the late $1930 \mathrm{~s}$. The simple reason for that is that when he started his own series of publications of evolution (in the late 1920s) he did so in a completely modern way on the basis of theoretical and empirical studies of population genetics (he had studied biogeography, genetics, clines and local adaptations of Pulsatilla), negating differences between macro- and microevolution and emphasizing the ubiquity of selection-controlled adaptation (Zimmermann 1934-1935). In a way Zimmermann single-handed accomplished a synthesis many years before other synthesists! There is no doubt that Zimmermann's books despite their wide distribution had little influence on the German discussion of evolution. Zimmermann's influence was weak because he never became a full professor and because he was dominated by typological morphologists such as Wilhelm Troll before and after 1945 and by plant systematists with little interest in evolution such as Karl Mägdefrau and by plant physiologists such as Erwin Bünning after 1945.

There is no doubt about Zimmermann's lack of success with respect to the propagation of his ideas. Yet it is interesting to note that by 1930 Zimmermann (in contrast to practically all his colleagues in Russia, German, England and the USA) was optimistic enough to think that there were enough data from genetics, empirical and theoretical population genetics, biogeography, morphology, paleontology and systematics to extrapolate to evolutionary theory and propose that mutation, recombination, selection and isolation are the relevant factors of evolution, that neo-Lamarckian mechanisms cannot be supported, that evolution is always gradual and that microevolution is not different from macroevolution (for Zimmermann's methodology of phylogenetics see Donoghue \& Kadereit 1992).

Wilhelm Ludwig (1933-1943)

Ludwig was the leading German theoretical population geneticist and selection theorist and was fully familiar with the international literature. $\mathrm{He}$ started to analyze mathematically the effect of low selection coefficients as 
early as 1933 . Nevertheless he is usually forgotten as a German representative of theoretical population genetics. Ludwig (1943, for his contribution to Heberer's Evolution der Organismen, see Reif 1999 a) gave an explication of selection theory that was in full accordance with the Synthesis. However, he was remarkably tolerant with respect to neo-Lamarckians and anti-selectionists. As late as 1938 he argued for further efforts to find non-selectionist evolutionary mechanisms and referred to his own Lamarckian experiments (see Behrendt 1939). These experiments had been completely negative and Ludwig came to the conclusion that if Lamarckian effects exist they operate very slowly (Ludwig 1939, p. 202). In his later articles $(1940,1943)$ Ludwig presented himself as a neutral observer of the various theories of evolution, without openly speaking out for one side. According to his own classification, however, he was no proponent of the Synthesis. He clearly belonged to the group of anti-selectionists (his own terminology!), which includes those biologists who think that the theory of selection is not sufficient (Ludwig 1943, p. 518). What Ludwig calls "selectionism" or "the theory of selection" is actually what we would now call the Synthetic Theory, i. e. including mutability and population effects. After 1945 Ludwig even took sides for Lysenko in the cautious way that was characteristic for him (1949-1950).

Ludwig is an interesting case because he understood the microevolutionary mechanism of the Synthesis (including its mathematics) and was able to present it in a convincing way to a broad audience. On the other hand he never accepted this theory as sufficient and strongly sympathized with unknown non-selectionist factors.

\section{Alfred Kühn $(1935,1939)$}

Two publications of the geneticist and developmental geneticist Kühn are of importance in the present context. In his paper of 1935 Kühn based his conclusion that random mutations and natural selection are the only factors controlling the differentiation of races and speciation on (1) developmental genetic results of Goldschmidt and himself, (2) the study of natural populations by Baur and Timoféeff-Ressovsky, (3) theoretical population genetics (Ludwig), and (4) biogeography of species (Rensch, Mayr and Stresemann). Kühn concluded that it is "not yet" possible to claim that selection and mutation are the only evolutionary factors in existence (Kühn 1935, p. 10). In his 1939 text-book Kühn defined species as reproductive communities and gave an extensive overview of the biogeography of races and species and their local adaptations and genetic differentiation. In the bibliography he quoted selectionists who were convinced that macroevolution can be extrapolated from microevolution (Dobzhansky 1939; Melchers 1939; Timoféeff-Ressovsky 1939 a; Zimmermann 1938). At the same time he called for more studies of the biochemistry and biophysics of genes and mutations, of 
developmental genetics and for genetic studies of natural populations as a future basis for a reliable knowledge of all factors of evolution: "Only experiment and not speculation can lead to progress" (p. 156). Harwood (1993) gives a thorough analysis of Kühn's ideal of Bildung and his stance against specialistic pragmatism and reductionism. It remains open, however, why he sticked to the ideal of strict empirism and methodological rigor with respect to macroevolution and was not just as "optimistic" as Dobzhansky (see Dobzhansky 1937, p. xv). In hindsight it is easy to state that this kind of optimism paid: "There were good reasons for its [= Synthetic Theory] adoption as a belief-governing policy" (Shapere 1980, p. 394).

\section{William Frederik Reinig (1935-1939)}

If we include among the architects those authors who studied the significance of the five evolutionary factors in natural populations, Reinig must count as an important contributor to the Synthesis. Reinig (1935, 1937, 1938, $1939 \mathrm{a}, \mathrm{b})$ studied natural variability in complex populations of birds and insects. As a member of the "Genetic Colloquium" in Berlin that was founded and organized by Timoféeff-Ressovsky (Reinig 1938, p. VI) he was familiar with all aspects of modern evolutionary biology (the "Genetic Colloquium" in Berlin must have been analogous to the "New York Circle"; see Senglaub 1978, Harwood 1993). Reinig wanted to know how the variability of populations was influenced by the reduction of their areal distribution in the Pleistocene and their redispersal after the Pleistocene. In other words he tried to reconstruct the evolutionary history of populations. He emphasized that this research program went much further than Rensch's biogeography of lower taxonomic units.

His result was that drift (which he called "Elimination" = the stochastic loss of genetic variability of populations) plays a significant role compared to selection. Important intra-populational characters in local demes can not be regarded as selection-driven adaptations to the local conditions but they are due to the random loss or accidental dominance of genes during the migration and dispersal of the populations. The basis of his studies are the evolutionary factors (1) random (micro)mutations, (2) recombination and (3) selection. (4) Drift and (5) isolation are the focus of his empirical studies. Implicitly and with reference to Dobzhansky Reinig agrees that these five factors can explain all of evolution (Reinig 1939 b, p. 305). Reinig did not explicitly deal with the fossil record or with other problems of macroevolution (origin of higher taxa etc.).

\section{Klaus Pätau and Georg Melchers (1939)}

Pätau and Melchers each published only one short paper in favor of the Synthesis. The papers were based on talks that had been given at the 13th annual meeting of the German society for genetics (Würzburg, September 
1938). At that time Pätau and Melchers worked at the Kaiser-Wilhelm-Institute for biology with Max Hartmann and Fritz von Wettstein as their directors. According to the autobiographical recollections of Melchers, he (and probably Pätau) were asked by von Wettstein and Hartmann to give their 'synthetic' talks, and at least Melchers was not very happy with the outcome (Melchers 1987, p. 387). Their talks were presented to supplement Timoféeff-Ressovsky's talk on "Genetics and evolution".

Melchers' paper on genetics and evolution from a botanical perspective was one of the first successful attempts to discuss the theories of the Synthesis in light of the botanical evidence. He mostly dealt with the question of mutability in the laboratory and in nature. He emphasized the importance of experimental (transmission) genetics for evolutionary theory and gave an overview of mutation, selection, isolation and drift. (German geneticists were at that time heavily fighting with the problem of inheritance that was caused by extranuclear factors and that we now know as the genomes of mitochondria and plastids). There was no discussion of population effects. Melchers did not explicitly stress the fact that microevolutionary factors can be extrapolated to macroevolution, but he speculated that there might be other evolutionary factors so far missing in the Synthesis. Pätau's article on the mathematical aspects of evolution is a comparatively short, but clear introduction to the mathematical theory of population genetics and evolution. His account is based on the theories of Fisher, Wright, and Dobzhansky. Taken together, the 1939 papers by Pätau, Melchers, Reinig and Timoféeff-Ressovsky are the first significant presentations of the new Synthesis as it had been laid out by Dobzhansky (1937) to the German audience.

\section{Bernhard Rensch (1939-1947)}

Rensch's major contribution to the second phase ("Preparation") of the Synthesis was his analysis of the biogeography of lower taxonomic units, the discovery of ring species and the high differentiation of species populations into local populations (summarized as early as 1929 but apparently with little influence of the international audience! On Rensch's early Lamarckian ideas see Junker 2000 c). Rensch's series of publications that contributed to the Synthesis starts with "Typen der Artbildung” (1939), which was published in an international journal, but was also not read internationally, either because of its misleading title ("Typen") or because it was written in German. Rensch developed a highly intriguing argument: Systematics and biogeography at the lowest taxonomic levels (races and species) are the first possible test of the sufficiency of the evolutionary factors (mutation, recombination, selection, isolation and drift). Rensch showed that - depending on the relative strengths of the factors - different kinds of speciation can be distinguished. There is no support of internalistic or holistic 
agencies in evolution. Rensch provided a wonderful example of "mutual enlightenment" (we borrow this term from Willi Hennig): (1) Biogeography and taxonomy (morphology) test the five factors of evolution; (2) the five factors of evolution help to understand biogeographical and morphological phenomena. (This papers deserves to be analyzed in more detail).

In 1943 Rensch expanded his strategy to test the five factors of evolution by considering "paleontological rules of evolution", i.e. patterns in the fossil record as they were reported by paleontologists. Rensch's main conclusion was that the patterns of (macro-)evolution can be explained largely by selection (Rensch $1943 \mathrm{a}$ ). However, he also admitted detrimental "overspecialization" (caused, for example, by allometric growth factors) that could lead to extinction. "Overspecialization" as a cause of extinction is not in accordance with the view of the Synthesis. Nevertheless it was taken into consideration by paleontologists well into the 1970 s (Reif 1975). In his book of 1947 Rensch (see Reif 1983, 1999 a; Popov \& Hoßfeld 2000) first discussed the factors of microevolution. He emphasized that he attributed local differentiations of population more to selection than to drift in contrast to Reinig. The main part of the book is devoted to macroevolution. In order to demonstrate that the same factors control macroevolution that control microevolution Rensch used a large number of examples of patterns of evolution derived from the fossil record and from comparative morphology of animals. Rensch's main strategy was to show that patterns of evolution do not prove autogenetic mechanisms but rather can be explained by selection and other microevolutionary mechanisms. Being remarkably tolerant with respect to autogenetic explanations of paleontologists Rensch admitted that there are "overspecializations" and other nonadaptive phenomena that have to be attributed to allometry, genetic lability and genetic aging.

Simpson (1949b) stated that central Europe and the West had been isolated "for some ten years" (p. 178) and interpreted Rensch (1947), together with Schindewolf (1945) and Zimmermann (1948) as "evolutionary phenomena of intellectual isolation". Simpson thus contributed much to the "isolation hypothesis" (the political situation of the Third Reich and especially World War II isolated the German scientific community completely from the rest of the world) that helped to establish the idea (see Mayr, above) that the German Synthesis was a "closely congruent" (Simpson 1949 b, p. 178), convergent, parallel event to the Anglo-American Synthesis (see conclusions).

\section{Fritz von Wettstein (1939) and Wettstein \& Hans Stubbe (1941)}

The botanist von Wettstein (1939) defended the basic principles of microevolution and proposed genetic mechanisms (that were within the framework of the accepted mechanisms of genetics) to explain the macroevolutionary phenomena of the evolution of new characters and of evolutionary 
trends (see Reif 1999a). In 1941 he published an article together with Stubbe on the importance of micro- and macromutations. They came to the conclusion that experimental and theoretical evidence made it impossible for the time being to decide whether evolutionary change is exclusively brought about by undirected micromutations or by micro- and macromutations. Macromutations could play a considerable directing force. (In hindsight, their problem was caused by the fact that they did not expect that selection acts on very small phenotypic differences.)

\section{Hans Nachtsheim (1940)}

Nachtsheim published several review articles which demonstrate his sympathy with the Synthesis. In 1927 he strongly criticized Richard von Wettstein who had rejected any relevance of genetics for the study of evolution (R. v. Wettstein 1928). To refute this pessimistic opinion Nachtsheim gave a short account of the latest developments in genetics that are relevant for the theory of evolution. He specifically mentioned Erwin Baur's findings about the high frequency of small mutations (Nachtsheim 1927, pp. 990991; Baur 1924, 1925). In 1940 he published a paper on the fundamental principles of race formation. The article is written from the perspective of the Synthesis. As contributing disciplines he mentioned paleontology, systematics, comparative anatomy, embryology and especially genetics (Nachtsheim 1940, p. 552). His list of summarizing accounts includes Rensch (1939), Reinig (1938), Timoféeff-Ressovsky (1939a), Melchers (1939), Dobzhansky (1937), and Zimmermann (1938). He particularly emphasized that it is legitimate to assume that there are no specific macroevolutionary factors (Nachtsheim 1940, p. 558).

\section{Gertraud Haase-Bessell (1941)}

Haase-Bessell was a geneticist and biophysicist who developed models of the physical and chemical structure of the gene. Very little is known about her life. There is not even a bibliography of her work (see Haffer 1999, p. 137-138). Haase-Bessell's two publications on evolution of 1941 are a short book and a semi-popular article. Both are summaries without bibliographies (the author planned longer accounts for the future). Haase-Bessell emphasized that recent developments in population genetics, cytogenetics and paleontology had helped to overcome the deadlock of evolutionary discussion of earlier decades (when typology and macroevolutionary speculations had dominated) and that they are striving strongly towards a "synthesis" (Haase-Bessell 1941 a, p. 233; 1941 b, p. III).

She gave a full account of cytogenetics, theoretical genetics and of the geographical variability of populations and ring-species, based on (1) random (micro-)mutations, (2) selection (which is regarded as a creative force), (3) isolation and (4) random loss of genes (due to fluctuating population sizes 
and migration of populations). (The fifth factor, recombination, is discussed implicitly in the principles of population genetics). Haase-Bessell emphasized the strong genetical polymorphism of populations and rejected Lamarckian inheritance and any kind of typology of taxonomists and paleontologists (especially that of Schindewolf). According to the author genetic and cytogenetic data have shown that life is monophyletic. Mutations are random with respect to the adaptive requirements, but they are not totally random, because of the inherent molecular structure of the genes. Evolution is a gradual, continuous change of populations. HaaseBessell did not deal especially with macroevolution but emphasized that the same evolutionary laws act everywhere (Haase-Bessell 1941 b, p. 39).

\section{Gerhard Heberer (1943)}

Heberer influenced the evolutionary Synthesis in Germany in two ways: First, he organized and edited Die Evolution der Organismen (1943 a). This collection is the most comprehensive statement of the Synthesis that was published during its formation phase in Germany. It resembles J. Huxley's The New Systematics (1940; see Hoßfeld 1997). The nineteen authors predominantly argue from a selectionist point of view and are opposed to Lamarckian, saltationist and orthogenetic theories although they sometimes leave room for non-selectionist factors. They were all Darwinians, but only Heberer, Rensch, Timoféeff-Ressovsky and Zimmermann can be considered architects of the Synthesis in a strict sense. The topics in the book range from a philosophical analysis of the theory of descent (Dingler 1943) and the refutation of typology (Zündorf 1943; see also Zündorf 1939-1942), to biological proofs of the theory of descent, methods of phylogenetics, ethology, phylogeny of plants, animals and man and population genetics, selection theory and macroevolution. Heberer clearly succeeded in bringing together a Darwinian synthesis that included a wide range of biological disciplines (Hoßfeld 1999).

Second, in his own article in Die Evolution der Organismen ("Das Typenproblem in der Stammesgeschichte", "The type problem in phylogeny"), Heberer suggested a selectionistic and gradualistic theory of macroevolution (Heberer 1943 b). He showed that there is no difference between the origin of taxa ("typogenesis") and their adaptation ("adaptogenesis"). Types, i. e. taxa, do not evolve in jumps but rather gradually. All phenomena of micro- and macroevolution, including phases of rapid evolutionary change, can be explained by the theory of selection.

\section{Franz Schwanitz (1943)}

The botanist Schwanitz summarized genetics and population genetics of plants in 1943 (see Reif 1999a). His view of microevolution is in accordance with the Synthesis. Schwanitz saw no reason to accept macroevolu- 
tionary laws; however, he was willing to concede that higher taxa and complex characters could originate from macromutations (see Stubbe \& Wettstein 1941).

\section{German Bridge-Builders and the Lack of Success of the German Synthesis}

According to Ernst Mayr (1980a, pp. 40-41) the Anglo-American architects of the Synthesis were especially suited for this task because they were bridge-builders with a very wide scientific interest and with interdisciplinary research experience. This is obviously also true for those German biologists working at the fore-front of the Synthesis. There is hardly any doubt that Erwin Baur, Max Hartmann, Gertraud Haase-Bessell, Hans Bauer, Walter Zimmermann, Gerhard Heberer and Bernhard Rensch had a classical high-school education ("klassische Bildung") and had profited from a very broad training during their university studies. Intensive interdisciplinary research experience can be found in the works of Baur (laboratory genetics, population genetics), Hartmann (transmission genetics, developmental genetics, general biology), Zimmermann (systematics of lower and of higher plant taxa, genetics, biogeography of clines and demes, ecology, paleontology), Timoféeff-Ressovsky (genetics, population genetics), Heberer (biogeography, comparative morphology, cytology, systematics) and Rensch (biogeography, taxonomy of lower taxonomic units, ecology, comparative morphology and embryology). This shows that a welding of laboratory biology and naturalistic biology (that was regarded as so important for the formative years of the Synthesis by Mayr) had a long tradition in Germany!

All these German authors were largely convinced that the five factors (mutations, recombination, selection, isolation and drift) were sufficient to explain microevolution and they saw no immediate need to suggest additional factors for macroevolution. There are other reasons why only Rensch's book (1947) was recognized by the international audience as relevant contribution to the Synthesis:

- German articles (in German journals, and even in international journals, such as Rensch 1939) were not read internationally, at least not after 1945 (Hoßfeld 1998 a, pp. 129-130).

- Zimmermann $(1930,1938)$ had had not much influence in Germany and virtually no international audience. Zimmermann book of 1948 can only be understood if one knows his 1930- and 1938-books. This is why Simpson (1949) could not deal in a fair way with Zimmermann (1948).

- Timoféeff-Ressovsky and Heberer did not write single-author books.

- Zimmermann and Heberer were not very successful in formulating their ideas in an easily accessible way. 
- Heberer's multi-author book never had an international audience (there were many reasons for this; Hoßfeld \& Junker 1998; Hoßfeld 1999).

- Heberer never wrote a long treatise of modern evolutionary thought after the war (Hoßfeld 1997).

- There was no German paleontologist to react against Schindewolf (Schindewolf's critics were rather weak, see Reif 1986, 1993, 1997, 1999 a). This led to the fact that Schindewolf's magnum opus (1950) and his publications after the war completely dominated the German scientific community of paleontologists (Reif 2000 a).

- Timoféeff-Ressovsky was taken back by the Soviet Army to the Soviet Union in 1945 (Voroncov 1993).

- Heberer, Rensch and Zimmermann had little influence on the discussion of evolution in German zoological and botanical circles after World War II (Kraus \& Hoßfeld 1998; Reif 2000 a; Junker 2000 b).

\section{Conclusions}

1) The development of Darwin's evolutionary theory can be divided into three stages: a) Original Darwinism (characterized by a pluralism of hard and soft inheritance, after 1859), b) Neo-Darwinism (characterized by hard inheritance, after 1885), c) Synthetic Theory (characterized by an emphasis of selection and other processes that take place within and between populations; it was completed in the late $1940 \mathrm{~s}$; the process that led to the Synthetic Theory is called Evolutionary Synthesis).

2) The Synthetic Theory is understood (with a structuralistic perspective) as a theory-complex that includes closely interconnected core-theories (mutation, recombination, natural selection, isolation, drift, i.e. processes that take place in and between individuals and in and between populations) and specifically excludes other hypotheses (orthogenesis, internalism, saltationism etc.). The relative importance of the evolutionary factors is still discussed. With regards to macroevolution the historical aspects of the evolutionary process are emphasized but no new factors of evolution are introduced. Hierarchical models that claim independent evolutionary roles for higher units of complexity (species, ecosystems etc.) cannot be regarded as useful expansions of the Synthetic Theory.

3) Biologists, historiographers and philosophers of science do not agree whether the Synthesis was as sudden event (spanning the time between 1937 and 1950) or whether it was a long-term event (starting no later than 1930), whether it was an international affair (that had its roots in the Soviet Union) or whether it was largely an Anglo-American affair, whether it was a scientific revolution or a fusion of research traditions (experimentalism and naturalism) or whether it was an eradication of anti-Darwinian and/or untestable hypotheses (orthogenesis, internalism etc.) or whether it 
was a harmonization of theory-complexes of population genetics, comparative morphology, systematics and paleontology.

4) In order to put the historiography of the Synthesis on a firmer basis we distinguish four phases: (1) Roots (1920 and before): Mendelian genetics, mutation theory, chromosome theory of inheritance etc. (2) Preparation (1920s and early 1930s): empirical and mathematical analysis of natural populations, biogeography of demes, populations and other low taxonomic units. (3) Formation = process of the Synthesis (early $1930 \mathrm{~s}$ to 1950): harmonization of population genetics, systematics, comparative morphology and paleontology, extrapolation of the five microevolutionary factors mutation, recombination, selection, isolation and drift - to macroevolution. (4) Reception (after 1950): application of the Synthetic Theory in modern research projects of population biology, ecology, systematics, biogeography, comparative morphology and paleontology.

5) In contrast to a widely accepted historiographical view the Evolutionary Synthesis was an international project. This is not only demonstrated by the fact that the Synthesis had its first origins in the Soviet Union. They were transferred to Germany by Timoféeff-Ressovsky (1925) and to the USA by Dobzhansky (1927; see Adams 1994). Additional evidence for its international character is provided by the significant number of German biologists who contributed to the Synthesis. It therefore seems much better to regard the Synthesis as an international long-term project (starting no later than 1930) than as a kind of a scientific revolution starting with Dobzhansky's Genetics and the Origin of Species (1937) and coming as a surprise for most biologists (see Bauer 1938; Brito da Cunha 1988; Mayr 1999b). Dobzhansky's book provided no new theory but summarized the necessary experimental and field data to evaluate the five evolutionary factors (mutation, recombination, selection, isolation and drift). However, there is no doubt that Dobzhansky's book can be regarded as the first account that convinced a wide readership and summed up the results of the aimed at Synthesis.

6) Our account of some of the more important contributions to the Synthesis by German authors supports some general impressions: Biologists from various areas were interested in the Synthesis. The largest group were the geneticists (botanical as well zoological genetics): Baur, Hartmann, Timoféeff-Ressovsky, Kühn, Melchers, von Wettstein, Stubbe, Nachtsheim, Haase-Bessell, and Schwanitz. These authors were primarily interested in the genetic basis of the Synthesis and in microevolution. The most original and important authors in this group were Baur and Timoféeff-Ressovsky.

7) Mathematical population genetics was represented by Pätau and Ludwig. Pätau's publication was only a competent literature review; Ludwig's much more sophisticated accounts contained also some original ideas. Systematics and biogeography were dealt with by Baur, Timoféeff-Ressovsky, 
Reinig, Zimmermann, and Rensch. Rensch did original research on speciation and microsystematics and integrated these otherwise neglected ideas. Zimmermann's special fields of interest were genetics, ecological biogeogeography and the classification of higher taxa. The integration of macroevolution and paleontology into the Synthesis was a major concern of Zimmermann, Rensch and Heberer. Heberer's (1943 b) article is written from a theoretical perspective. Rensch's much more extensive papers and book give a large amount of empirical evidence in addition. Neither Rensch nor Heberer were paleontologists!

8) Nearly all of the authors (but clearly not Zimmermann) sympathized vaguely with some kind of additional factor of evolution: directed mutations, macromutations, or elimination were mentioned frequently. Only a minority took it for granted that the known microevolutionary mechanisms are sufficient to explain all evolutionary phenomena. These factors were not necessarily seen as a refutation of the Synthesis, but as complements.

9) Our account demonstrates that during the $1920 \mathrm{~s}, 30 \mathrm{~s}$ and $40 \mathrm{~s}$ a rather large group of biologists in Germany was interested in Darwinian evolution and worked on problems from the perspective of the Synthesis. Zimmermann's Die Phylogenie der Pflanzen (1930) and his Vererbung “erworbener Eigenschaften" und Auslese (1938) had many drawbacks in comparison to Dobzhansky (1937) in addition to the fact they were written in German. The most ambitious publication that summarized the modern development of evolutionary biology in Germany and that aimed at a Synthesis was Heberer's Die Evolution der Organismen (see the contributions to Junker \& Engels 1999; Hoßfeld 1997, 1998 b, 1999; Junker 1999; Reif 1986, 1999a).

10) The German authors were well aware of the synthetic movement in Great Britain and the USA, and vice versa. Neither Baur, Zimmermann, Timoféeff-Ressovsky nor Rensch would have regarded their research as "German". They worked on the Evolutionary Synthesis in Germany and published in German, but the produced no "German" version of the Synthesis. The notion of a "German" version of the Synthesis is sometimes inferred from the seeming lack of communication during the years of the Third Reich and especially the war. Simpson (1949b), for example, claims that the scientific isolation between Central Europe and the USA had lasted for more than ten years, i. e. it began before 1939. This isolation hypothesis is very problematic because it is the basis for the idea that the German Synthesis was a convergent, parallel event to the Anglo-American Synthesis (e.g. Mayr 1988, p. 549). Implicitly this parallelism has been used by some American authors as a test of the Synthetic Theory. If the Germans came to the same conclusion as the Americans the Synthetic Theory must be correct. However, if one regards the Synthesis as a longterm project (starting no later than the early $1930 \mathrm{~s}$ ) and dates the isolation 
only to the years 1942 to 1947 the "German Synthesis" was not independent from the "Anglo-American Synthesis".

11) German biologists participated in the preparation and formation of the Synthesis. After the war there was almost no German contribution to the reception of the Synthetic Theory, i.e. very few research programs were directly influenced by the Synthetic Theory (see e.g. Barthelmess 1952). This development is significant and it explains, at least in part, why the German contributions to the Synthesis were more or less forgotten (Junker 2000 b; Reif 2000 a; Zachos \& Hoßfeld 2000).

12) The fact that the historiography of the Synthesis was almost completely restricted to the USA was in part due to the language barrier and the general neglect of German science after 1945. For Germany other influences have to be taken into consideration. The most decisive factor was probably the alleged close connection between genetics, the theory of evolution, and national socialism. Historians interested in the history of scientific ideas were put off by the prospect of dealing with predominately pseudo-scientific ideological concepts. Social historians on the other hand published some accounts of German biology during the Third Reich, but their special interest in the political context reinforced the impression that the theory of evolution was mainly a political theory (e. g. Weingart, Kroll \& Bayertz 1989; Deichmann 1992; see also Junker 1996 b, 2000 a; Hoßfeld 1997, 1998 b, 2000; Junker \& Paul 1999; Junker \& Hoßfeld 2000). With the exception of publications by Reif $(1983,1986)$ only in the last few years this situation has begun to change and a growing interest in the scientific concepts that were discussed during the $1930 \mathrm{~s}$ and $40 \mathrm{~s}$ in Germany can be observed (see Junker \& Engels 1999; Brömer, Hoßfeld \& Rupke 2000; Hoßfeld \& Brömer 2000, in prep., July 2000).

13) In hindsight, i. e. after 1950, Mayr and Simpson saw the Synthesis as a kind of Gestalt-switch that had been caused by Dobzhansky Genetics and the Origin of Species (see f.e. Mayr 1999 b, p. xv). Our results, however, show that many biologists (in the Soviet Union, in Germany, England and in the USA) worked towards a synthesis (i. e. a harmonization of population biology, biogeography, systematics and paleontology) since the early $1930 \mathrm{~s}$ (Zimmermann completed this harmonization for himself as early as 1930). If one avoids the 'hard' historiography, which has become the largely accepted version in the USA, many problems vanish: (a) The Synthesis was an international affair, and it was not formed by two parties during World War II in mutual isolation. (b) The Synthesis was no scientific revolution or an otherwise unique or difficult to explain process. Rather it was a rational interdisciplinary research project in which many biologists of several countries were involved, that was only moderately reductionistic (it focussed on the five evolutionary factors that control microevolution and - by inference - also macroevolution and it expelled anti-Darwinian and/or untestable speculations, such as orthogenesis, systemic mutations, 
saltationism etc.; see Junker in print c). (c) The so-called "architects" of the Synthesis (Dobzhansky, Huxley, Mayr, Simpson, Stebbins, Rensch) did not work in isolation. Rather they were successful and fast in giving interdisciplinary accounts of the modern views of evolution on the basis of their research experiences and their broad interests. There were other synthesists whose books were not so successful (Haase-Bessell, Reinig, Heberer, and especially Zimmermann) and synthesists who did not write books on evolution (Baur, Timoféeff-Ressovsky, etc.) (d) Because of the unfavorable institutional situation of evolutionary biology and the strong ideological opposition against the Darwinian research tradition the reception of the Synthetic Theory was delayed in Germany after 1945. In the Anglo-American countries, on the other hand, there was an intensive reception of the Synthetic Theory and an ongoing discussion of the unity of evolutionary biology and the expansion of the Synthetic Theory. However, up to the present we find no significant expansion or - let alone - refutation the Synthetic Theory.

\section{Acknowledgements}

We thank Prof. Dr. Dr. Olaf Breidbach for his interest in this project. WER thanks the Department of Geology and Paleontology for supporting his research and D. Metzger for significant technical help. We especially have to thank Ernst Mayr for his extensive comments on an early version of this paper.

\section{References}

Adams, M. (1967) The founding of population genetics: Contributions of the Chetverikov school 1924-1936. J. Hist. Biol. 1: 23-39.

Adams, M. (1970) Towards a synthesis: Population concepts in Russian evolutionary thought, 1925-1935. J. Hist. Biol. 3: 107-129.

Adams, M. (1980 a) Severtsov and Schmalhausen: Russian morphology and the Evolutionary Synthesis. In: Mayr, E.; Provine, W. B. (eds) The Evolutionary Synthesis. Cambridge, Mass. Harvard University Press, pp 193-228.

Adams, M. (1980 b) Sergei Chetverikov, the Kol'tsov Institute, and the Evolutionary Synthesis. In: Mayr, E.; Provine, W. B. (eds) The Evolutionary Synthesis. Cambridge, Mass. Harvard University Press, pp 242-278.

Adams, M. (ed) (1994) The Evolution of Theodosius Dobzhansky: Essays on his Life and Thought in Russia and America. Princeton. Princeton University Press.

Alberch, P. (1982) Developmental constraints in evolutionary processes. In: Bonner, J. T. (ed) Evolution and Development. Berlin. Springer, pp 313-332.

Alberch, P. (1985) Developmental constraints: Why St. Bernards often have an extra digit and poodles never do. Amer. Nat. 126: 410-413.

Amundson, R. (1994) Two concepts of constraint: Adapationism and the challenge from developmental biology. Philos. Sci. 61: 556-578.

Antonovics, J. (1987) The evolutionary dys-synthesis: Which bottles for which wine? Amer. Nat. 129: 321-331. 
Ariew, A. (1998) Are probabilities necessary for evolutionary explanations? Biol. \& Philos. 13: $245-253$.

Arnold, A. J.; Fristrup, K. (1982) The theory of evolution by natural selection: A hierarchical expansion. Paleobiology 8: 113-129.

Arnold, S. J. (1992) Constraints on phenotypic evolution. Amer. Natur. 140 (Suppl.): S85S107.

Arnold, S. J.; Wade, M. J. (1984) On the measurement of natural and sexual selection: Theory. Evolution 38: 709-719.

Atkinson, J. W. (1992) Conceptual issues in the reunion of development and evolution. Synthese 91: 93-100.

Ayala, F. J. (1982) Beyond Darwinism? The challenge of macroevolution to the synthetic theory of evolution. Philos. of Science Association 2: 275-291.

Ayala, F. J. (1983) Microevolution and Macroevolution. In: Bendall, D. S. (ed) Evolution from Molecules to Men. Cambridge. Cambridge University Press, pp 387-402.

Barel, C. N. D.; Anker, G. C.; Hoogerhoud, R. J. C.; Goldschmidt, T. (1989) Constructional constraint and its ecomorphological implications. Acta Morphol. Neerl. Scand 27: 83109.

Barnett, S. A. (ed) (1962) A Century of Darwin. London. Mercury Books.

Barthelmess, A. (1952) Vererbungswissenschaft. Orbis Academicus, vol. II/2. Freiburg/ München. Alber.

Bauer, H. (1938) Review of Th. Dobzhansky "Genetics and the Origin of Species". Die Naturwiss. 27: 367-368

Bauer, H.; Timoféeff-Ressovsky, N. W. (1943) Genetik und Evolutionsforschung bei Tieren. In: Heberer, G. (ed) Die Evolution der Organismen. Jena. Gustav Fischer, pp 335-429.

Baur, E. (1919) Einführung in die experimentelle Vererbungslehre. 3.-4. Auf. Berlin. Gebrüder Borntraeger.

Baur, E. (1924) Untersuchungen über das Wesen, die Entstehung und die Vererbung von Rassenunterschieden bei Antirhinum majus. Bibliographica Genetica 4: 1-170.

Baur, E. (1925) Die Bedeutung der Mutation für das Evolutionsproblem. Z. indukt. Abst. u. Vererbungsl. 37: 107-116.

Baur, E. (1932) Artumgrenzung und Artbildung in der Gattung Antirrbinum, Sektion Antirhinastrum. Z. indukt. Abst. u. Vererbungsl. 63: 256-302.

Beatty, J. (1980) Optimal-design models and the strategy of model building in evolutionary biology. Phil. Sci. 47: 532-561.

Beatty, J. (1986) The Synthesis and the Synthetic Theory. In: Bechtel, W. (ed) Integrating Scientific Disciplines. Dordrecht, Nijhoff, pp 125-135.

Beatty, J. (1987) On behalf the semantic view. Biol. \& Philos. 2: 17-23.

Beatty, J. (1988) Ecology and evolutionary biology in the war and postwar years: Questions and comments. J. Hist. Biol. 21: 245-263.

Bechtel, W. (1986) Editor's commentary. In: Bechtel, W. (ed) Integrating Scientific Disciplines. Dordrecht, Nijhoff, pp 137-142.

Behrendt, R. (1939) Untersuchung über die Wirkungen erblichen und nichterblichen Fehlens bzw. Nichtgebrauchs der Flügel auf die Flugmuskulatur von Drosophila melanogaster. Z. wiss. Zool. 152: 129-158.

Bjorklund, M. (1996) The importance of evolutionary constraints in ecological time scales. Evol. Ecol. 10: 423-431.

Bock, W. J. (1979) The synthetic explanation of macroevolutionary change: A reductionist approach. In: Schwartz, J. H.; Rollins, H. B. (eds) Models and Methodologies in Evolutionary Theory. Bull. Carnegie Mus. Nat. Hist. 13: 20-69.

Boletzky, S. von (1997) Developmental constraints and heterochrony: A new look at offspring size in cephalopod molluscs. Geobios M. S. 21: 267-275.

Bowler, P. J. (1983) The Eclipse of Darwinism. Baltimore. John Hopkins University Press.

Bowler, P. J. (1984) Evolution. The History of an Idea. Berkeley. University of California Press.

Bowler, P. J. (1988) The Non-Darwinian Revolution. Reinterpreting a Historical Myth. Baltimore. John Hopkins University Press.

Brandon, R. N. (1981) A structural descriprion of evolutionary theory. Philos. Soc. Amer. 2: 427-439. 
Brandon, R. N. (1982) The levels of selection. Philos. Soc. Amer. 1982, 1: 315-323.

Brandon, R. N. (1986) Introduction. In: Bechtel, W. (ed) Integrating Scientific Disciplines. Dordrecht. Nijhoff, pp 109-112.

Brandon, R. N. (1990) Adaptation and Environment. Princeton. Princeton University Press.

Brandon, R. N.; Burian, R. M. (eds) (1984) Genes, Organisms, Populations: Controversies over the Units of Selection. Cambridge, Mass. MIT/Bradford.

Brito da Cunha, A. (1988) On Dobzhansky and his evolution. Biol. \& Philos. 13: 289-300.

Brömer, R.; Hoßfeld, U.; Rupke, N. A. (eds) (2000) Evolutionsbiologie von Darwin bis heute. Verhandlungen zur Geschichte und Theorie der Biologie, Bd. 4. Berlin. Verlag für Wissenschaft und Bildung.

Burian, R. (1988) Challenges to the evolutionary synthesis. Evolutionary Biology 23: 247269.

Cain, J. A. (1992) Building a temporal biology: Simpson's program for paleontology during an American expansion of biology. Earth Sci. Hist. 11: 30-36.

Cain, J. A. (1993) Common problems and cooperative solutions. Organizational activity in evolutionary studies, 1936-1947. Isis 84: 1-25.

Cain, J. A. (1994) Ernst Mayr as community architect: launching the Society for the study of evolution and the Journal Evolution. Biol. \& Philos. 9: 387-427.

Caplan, A. L. (1978) Testability, disreputability, and the structure of the Modern Synthetic Theory of Evoution. Erkenntnis 13: 261-278.

Carter, D. R.; Beaupré, G. S.; Padian, K. (1992) Evolutionary constraints imposed by skeletal developmental mechanics. Trans. Orthop. Res. Soc. 38th Ann. Mtg. 17(1): 95.

Charlesworth, B.; Lande, R.; Slatkin, M. (1982) A neo-Darwinian commentary on macroevolution. Evolution 36: 474-498.

Chetverikov, S. S. (1905) Volny Zizni. Dnevnik Zool. otg-nia o-va lubitelej estestvozn 3(6): $106-110$.

Chetverikov, S.S. (1926) Concerning certain aspects of the evolutionary process from the standpoint of modern genetics. Zhurnal Eksperimental'noi Biologii ser. A, 2, no. 1: 354. English Transl.: Proceedings of the American Philosophical Society 105 (1961): 167195.

Chetverikov, S. S. (1926) O nekotorych momentach evolutsionnogo processa s tochki zrenija sovremennoj genetiki. Zurnal Eksperimentalnoj Biologii 2(1): 3-54.

Craig, D. M. (1982) Group selection vs. individual selection: An experimental analysis. Evolution 36: 271-282.

Darden, L. (1986) Relations among fields in the evolutionary synthesis. In: Bechtel, W. (ed) Integrating Scientific Disciplines. Dordrecht. Nijhoff, pp 113-124.

Deichmann, U. (1992) Biologen unter Hitler - Vertreibung, Karrieren, Forschung. Frankfurt/ New York. Campus.

Dietrich, M. R. (1995) Richard Goldschmidt's heresies and the Evolutionary Synthesis. J. Hist. Biol. 28: 431-461.

Dingler, H. (1943) Die philosophische Begründung der Deszendenztheorie. In: Heberer, G. (ed) Die Evolution der Organismen. Jena. Gustav Fischer, pp 2-20.

Dobzhansky, Th. (1937) Genetics and the Origin of Species. New York. Columbia University Press. Deutsche Übersetzung von W. Lerche: Die genetischen Grundlagen der Artbildung. Jena. Gustav Fischer, 1939.

Dobzhansky, Th. (1951) Mendelian populations and their evolution. In: Dunn, L. C. (ed) Genetics in the 20th Century. New York. Macmillan, pp 573-589.

Dobzhansky, Th. (1955) A review of some fundamental concepts and problems of population genetics. Cold Spring Harbor Symp. Quant. Biol. 20: 1-15.

Dobzhansky, Th. (1959) Evolution of genes and genes in evolution. Cold Spring Harbor Symp. Quant. Biol. 24: 15-30.

Dobzhansky, Th. (1980) The birth of the genetic theory of evolution in the Soviet Union in the 1920 s. In: Mayr, E.; Provine, W. B. (eds) The Evolutionary Synthesis. Cambridge, Mass. Harvard University Press, pp 229-241.

Donoghue, M.; Kadereit, J. W. (1992) Walter Zimmermann and the growth of phylogenetic theory. Syst. Biol. 41: 74-85.

Dubinin, N. P. \& D. D. Romasov (1932) Geneticeskoje sroenie vida i ewo evoljucia. Biol. Zurn. 1(5-6): 52-95. 
Dudley, E. C. (1991) The Unity of Evolutionary Biology. 2 vols. Portland, Oregon. Dioscorides Press.

Eldredge, N. (1979) Alternative approaches to evolutionary theory. In: Schwartz, J. H.; Rollins, H. B. (eds) Models and Methodologies in Evolutionary Theory, Bull. Carnegie Mus. Nat. Hist. 13: 7-19.

Eldredge, N. (1982) Introduction. In: Mayr, E. Systematics and the Origin of Species. Reprint. New York. Columbia University Press, 1982, pp XV-XXXVII.

Eldredge, N. (1985) Unfinished Synthesis. Biological Hierarchies and Modern Evolutionary Thought. New York. Oxford University Press.

Eldredge, N.; Gould, S. J. (1972) Punctuated equilibria: an alternative to phyletic gradualism. In: Schopf, T. J. M. (ed) Models in Paleobiology. San Francisco. Freeman, Cooper, pp 89115.

Fisher, R. A. (1918) The correlation between relatives on the supposition of Mendelian inheritance. Trans. Roy. Soc. Edinburgh 52: 399-433.

Fisher, R. A. (1930). The Genetical Theory of Natural Selection. New York. Acad. Press; Oxford. Clarendon Press.

Fisher, R. A. (1931) The evolution of dominance. Biol. Rev. 6: 345.

Fisher, R. A. (1934) Professor Wright on the theory of dominance. Amer. Nat. 68: 370.

Fitch; W. M.; Ayala, F. J. (1995) Tempo and Mode in Evolution. Genetics and Paleontology 50 Years after Simpson. Washington. National Academy Press.

Franklin, I.; Lewontin, R. C. (1970) Is the gene the unit of selection? Genetics 65: 707-734.

Futuyma, D. J. (1986) Evolutionary biology. 2d ed. Sunderland, Mass. Sinauer Ass.

Gall, I. M. (1997) G. F. Gauze: Ekolog i Evolutsionist. St. Petersburg, Almanach.

Gall, I. M. (2000) G. F. Gause und der Darwinismus. In: Hoßfeld, U.; Brömer, R. (eds) Darwinismus und/als Ideologie. Verhandlungen zur Geschichte und Theorie der Biologie, Bd. 6. Berlin. Verlag für Wissenschaft und Bildung. (in prep.)

Gayon, J. (1990) Critics and criticism of the modern synthesis. The viewpoint of a philosopher. Evolutionary Biology 24: 1-50.

Gayon, J. (1998) Darwinism's Struggle for Survival: Heredity and the Hypothesis of Natural Selection. Transl. by Matthew Cobb. Cambridge: Cambridge University Press.

Glass, B. (1990) Timoféeff-Ressovsky, N. W. In: Holmes, F. L. (ed) Dictionary of Scientific Biography. Vol. 18, Suppl. II. New York. Scribner, pp 919-926.

Goldschmidt, R. (1927) Physiologische Theorie der Vererbung. Berlin: Springer.

Goldschmidt, R. (1935) Geographische Variation und Artbildung. Die Naturwiss. 23: 169-176.

Goldschmidt, R. (1940) The Material Basis of Evolution. New Haven and London. Yale University Press.

Goldschmidt, R. (1959) Erlebnisse und Begegnungen. Berlin, Hamburg.

Gould, S. J. (1980 a) Is a new and general theory of evolution emerging? Paleobiology 6: 119130.

Gould, S. J. (1980 b) G. G. Simpson, paleontology and the Modern Synthesis. In: Mayr, E.; Provine, W. B. (eds) The Evolutionary Synthesis. Cambridge, Mass. Harvard University Press, pp 153-172.

Gould, S. J. (1981) But not Wright enough. Paleobiology 7: 131-134.

Gould, S. J. (1982 a) Darwinism and the expansion of evolutionary theory. Science 216: 380387.

Gould, S. J. (1982 b) The meaning of punctuated equilibrium and its role in validating a hierarchical approach to macroevolution. In: Milkman, R. (ed) Perspectives on Evolution. Sunderland, Mass. Sinauer, pp 83-104.

Gould, S. J. (1983 a) Irrelevance, submission, and partnership: the changing role of paleontology in Darwin's three centennials, and a modest proposal for macroevolution. In: Bendall, S. (ed) Evolution from Molecules to Men. Cambridge. Cambridge University Press, pp 348-366.

Gould, S. J. (1983 b) The Hardening of the Modern Synthesis. In: Grene, M. (ed) Dimensions of Darwinism. Cambridge/Paris. University Press; Editions de la Maison des Sciences de l'Homme, pp 71-93.

Gould, S. J. (1995) Tempo and mode in the macroevolutionary reconstruction of Darwinism. In: Fitch, W. M.; Ayala, F. J. (eds) Tempo and Mode in Evolution: Genetics and Paleontology Fifty Years after Simpson. Washington, DC. Nation. Acad. Sci., pp 125-144. 
Gould, S. J.; Eldredge, N. (1977) Punctuated equilibria: The tempo and mode of evolution reconsidered Paleobiology 3: 115-151.

Grant, V. (1983) The synthetic theory strikes back. Biol. Zbl. 102: 149-158.

Grant, V. (1985) The evolutionary process. New York. Columbia Univ. Press. 2d ed. New York. Columbia Univ. Press, 1991.

Grene, M. (1990) Is evolution at a crossroads? Evolutionary Biology 24: 51-81.

Haase-Bessell, G. (1941 a) Evolution. Der Biologe 10: 233-247.

Haase-Bessell, G. (1941 b) Der Evolutionsgedanke in seiner heutigen Fassung. Jena. Gustav Fischer.

Haffer, J. (1997) Essentialistisches und evolutionäres Denken in der systematischen Ornithologie des 19. und 20. Jahrhunderts. J. für Ornithologie 138: 61-72.

Haffer, J. (1999) Beiträge zoologischer Systematiker und einiger Genetiker zur Evolutionären Synthese in Deutschland (1937-1950). In: Junker, T.; Engels, E.-M. (eds) Die Entstehung der Synthetischen Theorie. Berlin. Verlag für Wissenschaft und Bildung, pp 121-150.

Haldane, J. B. S. (1924-1932) A Mathematical Theory of Natural and Artificial Selection, Part I-IX. Proceedings of the Cambridge Philosophical Society (Biol. Sci.) 23-28.

Haldane, J. B. S. (1930) A note on Fisher's theory of the origin of dominance, and on correlation between dominance and linkage. Amer. Nat. 64: 87-90.

Haldane, J. B. S. (1931) The Philosophical Theory of Biology. London. Hodder \& Stoughton. Deutsch: Die Philosophie eines Biologen. Jena. Gustav Fischer, 1936.

Haldane, J. B. S. (1932) The Causes of Evolution. London. Harper.

Haldane, J. B. S. (1953) Foreword. Symposia of the Society for Experimental Biology 7: ix.

Hamburger, V. (1980) Evolutionary theory in Germany: A comment. In: Mayr, E.; Provine, W. B. (eds) The Evolutionary Synthesis. Cambridge, Mass. Harvard University Press, pp 303-308.

Harland, S. C. (1936) The genetical conception of the species. Biol. Rev. 11: 83-112.

Hartmann, M. (1933) Allgemeine Biologie. Eine Einführung in die Lehre vom Leben. 2d ed. Jena. Gustav Fischer.

Hartmann, M. (1939) Geleitwort. In: Th. Dobzhansky (1939) Die genetischen Grundlagen der Artbildung. Deutsche Übersetzung von W. Lerche: Jena. Gustav Fischer.

Harwood, J. (1993) Styles of Scientific Thought. The German Genetics Community 19001933. Chicago. Chicago University Press.

Heberer, G. (ed) (1943 a) Die Evolution der Organismen. Ergebnisse und Probleme der Abstammungsgeschichte. Jena: Gustav Fischer.

Heberer, G. (1943 b) Das Typenproblem in der Stammesgeschichte. In: Heberer, G. (ed) Die Evolution der Organismen. Jena. Gustav Fischer, pp 545-589.

Heberer, G. (1958) Zum Problem der additiven Typogenese. Uppsala Universitets Årsskrift, no. 6: 40-47.

Heberer, G. (ed) (1959 a) Die Evolution der Organismen. 2d ed. 2 Bde. Stuttgart. Gustav Fischer.

Heberer, G. (1959 b) Theorie der additiven Typogenese. In: Heberer, G. (ed) Die Evolution der Organismen. 2d ed. Stuttgart. Gustav Fischer, pp 857-916.

Hecht, M. K.; Hoffman, A. (1986) Why not neo-Darwinism? Oxford Rev. Evol. Biol. 3: 1-47.

Hoffman, A. (1989) Arguments on Evolution. A Paleontologist's Perspective. New York. Oxford University Press.

Hoffman, T.; Reif, W. E. (1994) Rudolf Kaufmann's work on iterative evolution in the Upper Cambrian trilobite genus Olenus: A reappraisal. Paläontologische Z. 68: 71-89.

Horan, B. L. (1994) The statistical character of evolutionary theory. Phil. Sci. 61: 76-95.

Hoßfeld, U. (1997) Gerhard Heberer (1901-1973) - Sein Beitrag zur Biologie im 20. Jahrhundert. Berlin. Verlag für Wissenschaft und Bildung.

Hoßfeld, U. (1998 a) Dobzhansky's Buch 'Genetics and the Origin of Species' (1937) und sein Einfluß auf die deutschsprachige Evolutionsbiologie. Jahrbuch für Geschichte und Theorie der Biologie 5: 105-144.

Hoßfeld, U. (1998 b) Die Entstehung der Modernen Synthese im deutschen Sprachraum. In: Welträtsel und Lebenswunder: Ernst Haeckel - Werk, Wirkung und Folgen. Stapfia; Bd. 56. Katalog des OÖ. Landesmuseums; N. F. 131. Linz. Gutenberg, pp 185-226.

Hoßfeld, U. (1999) Die Moderne Synthese und Die Evolution der Organismen. In: Junker, T.; Engels, E.-M. (eds) Die Entstehung der Synthetischen Theorie. Berlin. Verlag für Wissenschaft und Bildung, pp 189-225. 
Hoßfeld, U. (2000) Staatsbiologie, Rassenkunde und Moderne Synthese in Deutschland während der NS-Zeit. In: Brömer, R.; Hoßfeld, U.; Rupke, N. A. (eds) Evolutionsbiologie von Darwin bis heute. Berlin. Verlag für Wissenschaft und Bildung, pp 249-306.

Hoßfeld, U.; Brömer, R. (eds) (in prep., July 2000) Darwinismus und/als Ideologie. Verhandlungen zur Geschichte und Theorie der Biologie, Bd.6. Berlin. Verlag für Wissenschaft und Bildung.

Hoßfeld, U.; Junker, T. (1998) Dietrich Starck zum 90. Geburtstag. Intern Zs. f. Gesch. u. Ethik der Naturwiss., Technik u. Med. (NTM), N.S. 6: 129-147.

Hoßfeld, U.; Junker, T. (1999) Morphologie und Synthetische Theorie: Interview mit Dietrich Starck. In: Junker, T.; Engels, E.-M. (eds) Die Entstehung der Synthetischen Theorie. Berlin. Verlag für Wissenschaft und Bildung, pp 225-238.

Hoßfeld, U., T. Junker \& E. I. Kolchinsky (2000) (in print): Protagonisty i glavnyje naucnyje trudy po evolucionnomu sintezu $\mathrm{v}$ nemecko-jazycnom prostranstve. Voprosy Istorii Estestvoznanija i Technikiy (VIET), Nr. 1, Moskva: Nauka.

Huxley, J. S. (1936) Natural selection and evolutionary progress. Rep. Brit. Assoc. Advancement Sci 106: 81-100.

Huxley, J. S. (ed) (1940) The New Systematics. Oxford. Oxford University Press.

Huxley, J. S. (1942) Evolution. The Modern Synthesis. London. Allen Unwin.

Jepsen, G. L.; Cooper, K. (1946) Genetics, Paleontologyy and Evolution. Princeton. Princeton University Press.

Jepsen, G. L. (1949) Selection, orthogenesis, and the fossil record. Proc. Amer. Philos. Soc. 93: 479-500.

Jepsen, G. L.; Mayr, E.; Simpson, G. G. (1949) Genetics, Paleontology and Evolution. Princeton. Princeton University Press.

Journet, D. (1995) Synthesizing disciplinary narratives: George Gaylord Simpson’s Tempo and Mode in Evolution. Social Epistemology 9: 113-150.

Junker, T. (1989) Darwinismus und Botanik. Rezeption, Kritik und theoretische Alternativen im Deutschland des 19. Jahrhunderts. Stuttgart: Deutscher Apotheker Verlag.

Junker, T. (1995) Zur Rezeption der Darwinschen Theorien bei deutschen Botanikern (18591880). In: Engels, E.-M. (ed) Die Rezeption von Evolutionstheorien im 19. Jahrhundert. Frankfurt am Main. Suhrkamp, pp 147-181.

Junker, T. (1996 a) Factors Shaping Ernst Mayr's Concepts in the History of Biology. J. Hist. Biol. 29: 29-77.

Junker, T. (1996 b) Kulturpessimismus und Genetik: Von Weimar zum Dritten Reich. Biol. Zbl. 115: 145-152.

Junker, T. (1998 a) Charles Darwin und die Evolutionstheorien des 19. Jahrhunderts. In: Jahn, I. (ed) Geschichte der Biologie. 3d ed. Stuttgart, Jena. Gustav Fischer, pp 356-385.

Junker, T. (1998 b) Eugenik, Synthetische Theorie und Ethik. Der Fall Timoféeff-Ressovsky im internationalen Kontext. In: Engels, E.-M.; Junker, T.; Weingarten, M. (eds) Ethik der Biowissenschaften: Geschichte und Theorie. Berlin. Verlag für Wissenschaft und Bildung, pp 7-40.

Junker, T. (1999) Was war die Evolutionäre Synthese? Zur Geschichte eines umstrittenen Begriffes. In: Junker, T.; Engels, E.-M. (eds) Die Entstehung der Synthetischen Theorie. Berlin. Verlag für Wissenschaft und Bildung, pp 31-78.

Junker, T. (2000 a) Synthetische Theorie, Eugenik und NS-Biologie. In: Brömer, R.; Hoßfeld, U.; Rupke, N. A. (eds) Evolutionsbiologie von Darwin bis heute. Berlin. Verlag für Wissenschaft und Bildung, pp 307-360.

Junker, T. $(2000 \mathrm{~b})$ Adolf Remane und die Synthetische Theorie. In: E. Höxtermann et al. (eds) Geschichte der Meeresbiologie. Verhandlungen zur Geschichte und Theorie der Biologie, Bd. 5. Berlin: Verlag für Wissenschaft und Bildung.

Junker, T. (2000 c) Gab es politische Gründe für Bernhard Renschs Abwendung vom Lamarckismus in den Jahren 1933-1936 In: Hoßfeld, U.; Brömer, R. (eds) Darwinismus und/als Ideologie. Verhandlungen zur Geschichte und Theorie der Biologie, Bd. 6. Berlin. Verlag für Wissenschaft und Bildung. (in prep.)

Junker, T. (in print a) Walter Zimmermann. In: Schmitt, M.; Jahn, I. (eds) Darwin \& Co. Bd. 2. München. Beck Verlag.

Junker, T. (in print b) George Gaylord Simpson. In: Schmitt, M.; Jahn, I. (eds) Darwin \& Co. Bd. 2. München. Beck Verlag. 
Junker, T. (in print c) Ganzheit und genetisches Milieu: Holistische Ansätze in der modernen Evolutionstheorie. In: B. Boisitis und S. Rinofner-Kreidl (eds) Einheit und Vielheit: Organologische Denkmodelle in der Moderne. Studien zur Moderne, Bd. 7. Wien: PassagenVerlag.

Junker, T.; Engels, E.-M. (eds) (1999) Die Entstehung der Synthetischen Theorie: Beiträge zur Geschichte der Evolutionsbiologie in Deutschland 1930-1950. Verhandlungen zur Geschichte und Theorie der Biologie, Bd. 2. Berlin. Verlag für Wissenschaft und Bildung.

Junker, T.; Paul, S. (1999) Das Eugenik-Argument in der Diskussion um die Humangenetik eine kritische Analyse. In: Engels, E.-M. (ed) Biologie und Ethik. Stuttgart. Philipp Reclam jun., pp 161-193.

Junker, T.; Hoßfeld, U. (2000) Synthetische Theorie und ,Deutsche Biologie': Einführender Essay. In: Brömer, R.; Hoßfeld, U.; Rupke, N. A. (eds) Evolutionsbiologie von Darwin bis heute. Berlin. Verlag für Wissenschaft und Bildung, pp 231-248.

Kimura, M. (1983) The Neutral Theory of Molecular Evolution. Cambridge. Cambridge Univ. Press.

Kolchinsky, E. I. et al. (eds) (1994) Evolutionnaja teorija. St. Petersburg.

Kolchinsky, E. I. (ed) (1997) Na perelome. Sovetskaja biologija 20-30-h godach. St. Petersburg.

Kolchinsky, E. I. (1999) V poiskach sovetskogo “sojusa” folisofii i biologii. Diskussii i repressii v 20-ch - nacale 30-ch gg. St. Petersburg. D. Bulanin.

Kolchinsky, E. I. (2000 a) Ausgewählte Aspekte der Modernen Synthese im russischen Sprachraum zwischen 1920 und 1940. In: Brömer, R.; Hoßfeld, U.; Rupke, N. A. (eds) Evolutionsbiologie von Darwin bis heute. Berlin. Verlag für Wissenschaft und Bildung, pp 197210.

Kolchinsky, E. I. (2000 b) Kurzbiographien einiger Begründer der Evolutionssynthese in Russland (1920-1940). In: Brömer, R.; Hoßfeld, U.; Rupke, N. A. (eds) Evolutionsbiologie von Darwin bis heute. Berlin. Verlag für Wissenschaft und Bildung, pp 211-229.

Kraus, O.; Hoßfeld, U. (1998) 40 Jahre „Phylogenetisches Symposium“ (1956-1997): eine Übersicht - Anfänge, Entwicklung, Dokumentation und Wirkung -. Jahrbuch für Geschichte und Theorie der Biologie 5: 157-186.

Kühn, A. (1935) Physiologie der Vererbung und Artumwandlung. Die Naturwiss. 23: 1-10.

Kühn, A. (1939) Grundriß der Vererbungslehre. Leipzig. Quelle \& Meyer.

Laporte, L. F. (1983) Simpson's Tempo and Mode revisited Proc. Amer. Phil. Soc. 127: 365417.

Laporte, L. F. (1990) The world into which Darwin led Simpson. J. Hist. Biol. 23: 499-516.

Laporte, L. F. (1991) George G. Simpson, paleontology, and the expansion of biology. In: Benson, K. R.; Maienschein, J.; Rainger, R. (eds) The Expanson of American Biology, New Brunswick. Rutgers, pp 80-105.

Laporte, L. F. (1994) Simpson on Species. J. Hist. Biol. 27: 141-159.

Laudan, L. (1977) Progress and its Problems. Berkeley. University of California Press.

Leeper, G. W. (ed) (1962) The Evolution of Living Organisms. Melbourne. Melbourne University Press.

Levinton, J. (1988) Genetics, paleontology and macroevolution. Cambridge University Press.

Levinton, J. S. (1986) Developmental constraints and evolutionary saltations: A discussion and critique. In: Gustafson, J. P.; Stebbins, G. L.; Ayala, F. J. (eds) Genetics, Development, and Evolution. New York. Plenum, pp 253-288.

Levinton, J. S.; Simon, C. M. (1980) A critique of the punctuated equilibria model and implications for the detection of speciation in the fossil record. System. Zool. 29: 130-142.

Lewontin, R. C. (1970) The units of selection. Ann. Rev. Ecology and Systematics 1: 1-18.

Lewontin, R. C. (1972) Testing the theory of natural selection. Nature 236: 181-182.

Lewontin, R. C. (1978) Adaptation. Sci. Amer. 239: 156-169.

Lloyd, E. A. (1988) The Structure and Confirmation of Evolutionary Theory. Princeton. Princeton Univ. Press.

Ludwig, W. (1933) Der Effekt der Selektion bei Mutationen geringen Selektionswertes. Biol. Zbl. 53: 364-379.

Ludwig, W. (1939) Experimente zur Stammesentwicklung. Forsch. Fortschr. 15: 200-202.

Ludwig, W. (1940) Selektion und Stammesentwicklung. Die Naturwiss. 28 (1940): 689-705.

Ludwig, W. (1943) Die Selektionstheorie. In: Heberer, G. (ed) Die Evolution der Organismen. Jena. Gustav Fischer, pp 479-520. 
Ludwig, W. (1949-1950) Was ist Mitschurinismus? Homo 1: 245-250.

Ludwig, W. (1959) Die Selektionstheorie. In: Heberer, G. (ed) Die Evolution der Organismen. 2d ed. Stuttgart. Gustav Fischer, pp 663-712.

Lüers, H.; Ulrich, H. (1959) Genetik und Evolutionsforschung bei Tieren. In: Heberer, G. (ed) Die Evolution der Organismen. 2d ed. Stuttgart. Gustav Fischer, pp 552-662.

Mayr, E. (1942) Systematics and the Origin of Species. New York. Columbia University Press. Reprint with an New Introduction by the Author. Cambridge, Mass. Harvard University Press, 1999.

Mayr, E. (1954) Review of Zimmermann (1953). The Scientific Monthly 79: 57-58.

Mayr, E. (1959) Where are we? Cold Spring Harbor Symposium on Quantitative Biology 24: $1-14$.

Mayr, E. (1962) Accident or design: the paradox of evolution. In: Leeper, G. W. (ed) The Evolution of Living Organisms. Melbourne. Melbourne Univ. Press, pp 1-14.

Mayr, E. (1963) Animal Species and Evolution. Cambridge, Mass. The Belknap Press of Harvard University Press.

Mayr, E. (1973) The recent historiography of genetics. J. Hist. Biol. 6: 125-154.

Mayr, E. (1980 a) Some thoughts on the history of the evolutionary synthesis. In: Mayr, E.; Provine, W. B. (eds). The Evolutionary Synthesis. Cambridge, Mass. Harvard University Press, pp 1-50.

Mayr, E. (1980 b) Germany: Introduction. In: Mayr, E.; Provine, W. B. (eds) The Evolutionary Synthesis. Cambridge, Mass. Harvard University Press, pp 279-284.

Mayr, E. (1980 c) G. G. Simpson. In Mayr, E.; Provine, W. B. (eds) The Evolutionary Synthesis. Cambridge, Mass. Harvard University Press, pp 452-466.

Mayr, E. (1982) The Growth of Biological Thought. Cambridge, Mass. Harvard University Press.

Mayr, E. (1984) The triumph of evolutionary synthesis. The Times Literary Supplement, 2 November 1984, pp 1261-1262.

Mayr, E. (1988) On the Evolutionary Synthesis and after. In: Mayr, E. (1988) Toward a New Philosophy of Biology. Observations of an Evolutionist. Cambridge, Mass. Harvard University Press, pp 525-554.

Mayr, E. (1992) Controversies in retrospect. In: Futuyma, D.; Antonovics, J. (eds) Oxford Surveys in Evolutionary Biology 8: 1-34.

Mayr, E. (1993) What was the evolutionary synthesis? Trends Ecol. Evol. 8: 31-34.

Mayr, E. (1996) The modern evolutionary theory. J. Mammalogy 77: 1-7.

Mayr, E. (1999 a) Thoughts on the Evolutionary Synthesis in Germany. In: Junker, T.; Engels, E.-M. (eds) Die Entstehung der Synthetischen Theorie. Berlin. Verlag für Wissenschaft und Bildung, pp 19-30.

Mayr, E. (1999 b) Introduction. In: Mayr, E. Systematics and the Origin of Species. Reprint. Cambridge, Mass. Harvard University Press, pp xiii-xxxv.

Mayr, E.; Provine, W. B. (eds) (1980) The Evolutionary Synthesis. Perspectives on the Unification of Biology. Cambridge, Mass. Harvard University Press. With a New Preface by Ernst Mayr. Cambridge, Mass. and London. Harvard University Press, 1998.

Melchers, G. (1939) Genetik und Evolution (Bericht eines Botanikers). Z. indukt. Abst. u. Vererbungslehre 76: 229-259.

Melchers, G. (1987) Ein Botaniker auf dem Wege in die Allgemeine Biologie auch in Zeiten moralischer und materieller Zerstörung und Fritz von Wettstein, 1895-1945 mit Liste der Veröffentlichungen und Dissertationen (Persönliche Erinnerungen). Ber. Deutsch. Bot. Ges. 100: 373-405.

Mikulinsky, S. R.; Kolchinsky, E. I. (eds) (1983) Razvitije Evolutionoj Teorii v SSSR (19171970-e gody). Leningrad, Nauka.

Muller, H. J. (1949). The Darwinian and modern conceptions of natural selection. Proc. Amer. Phil. Soc. 93: 459-470.

Munson, R. (1975) Is biology a provincial science? Phil. Sci. 42: 428-447.

Nachtsheim, H. (1927) Der V. Internationale Kongreß für Vererbungswissenschaft. Die Naturwiss. 15: 989-995.

Nachtsheim, H. (1940) Allgemeine Grundlagen der Rassenbildung. In: Just, G. (ed) Handbuch der Erbbiologie des Menschen, Bd.1, Die Grundlagen der Erbbiologie des Menschen. Berlin. Julius Springer, pp 552-583. 
Olding, A. (1978) A defense of evolutionary laws. Brit. J. Phil. Sci. 29: 849-855.

Orzack, S. H. (1981) The Modern Synthesis in partly Wright. Paleobiology 7: 128-131.

Pätau, K. (1939) Die mathematische Analyse der Evolutionsvorgänge. Z. indukt. Abst. u. Vererbungsl. 76: 220-228.

Piternick, L. K. (1980) Richard Goldschmidt: Controversial Geneticist and Creative Biologist. Experientia Supplementum 35. Basel. Birkhäuser.

Popov, I. J. (1998) Znacenie issledovanij geograficeskoj izmencivosti dla formirovania evolucionnogo sinteza. Moskva.

Popov, I.; Hoßfeld, U. (2000): Bernhard Rensch - k 100-letiju so dnja rozdenija. Priroda (in press).

Provine, W. B. (1971) The Origins of Theoretical Population Genetics. Chicago. Chicago University Press.

Provine, W. B. (1978) The role of mathematical population genetics in the Evolutionary Synthesis of the 1930s and 1940s. Stud. Hist. Biol. 2: 167-192.

Provine, W. B. (1980) Epilogue. In: Mayr, E.; Provine, W. B. (eds). The Evolutionary Synthesis. Cambridge, Mass. Harvard University Press, pp 399-412.

Provine, W. B. (1988) Progress in evolution and meaning of life. In: Nitecki, M. H. (ed) Evolutionary Progress. Chicago. Chicago University Press, pp 49-74.

Reif, W.-E. (1975) Lenkende und limitierende Faktoren in der Evolution. Acta Biotheoretica 24: $136-162$.

Reif, W.-E. (1983) Evolutionary theory in German paleontology. In: Grene, M. (ed) Dimensions of Darwinism. Cambridge. Cambridge University Press, pp 173-203.

Reif, W.-E. (1986) The search for a macroevolutionary theory in German paleontology. J. Hist. Biol. 19: 79-130.

Reif, W.-E. (1993) Afterword. In: Schindewolf, O. H. (1950/1993) Basic Questions in Paleontology. Chicago. Chicago University Press, pp 435-453.

Reif, W.-E. (1997) Typology and the primacy of morphology: The concepts of O. H. Schindewolf. Neues Jahrb. Geol. Paläont. Abh. 205: 355-371.

Reif, W.-E. (1998) Review of Smocovitis (1996). Zentralbl. Geol. Paläont., Teil II (5/6): 268272.

Reif, W.-E. (1999 a) Deutschsprachige Paläontologie im Spannungsfeld zwischen Makroevolutionstheorie und Neo-Darwinismus (1920-1950). In: Junker, T.; Engels, E.-M. (eds) Die Entstehung der Synthetischen Theorie. Berlin. Verlag für Wissenschaft und Bildung, pp 151-188.

Reif, W.-E. (1999 b) Practice and Theory in Natural History: Domains and Epistemic Things. Theory Biosci. 118: 161-174.

Reif, W.-E. (2000 a) Deutschsprachige Evolutions-Diskussion im Darwin-Jahr 1959. In: Brömer, R.; Hoßfeld, U.; Rupke, N. A. (eds) Evolutionsbiologie von Darwin bis heute. Berlin. Verlag für Wissenschaft und Bildung, pp 361-396.

Reif, W.-E. (2000 b): Darwinism, gradualism and uniformitarianism. N. Jb. Geol. Paläont.

Reif, W.-E. (in prep.) Structural analysis and evaluation of evolutionary theories.

Reif, W.-E.; Thomas, R. D. K.; Fischer, M. S. (1985) Constructional morphology: The analysis of constraints in evolution. Acta. Biotheor. 34: 233-248.

Reinig, W. F. (1935) Über die Bedeutung der individuellen Variabilität für die Entstehung geographischer Rassen. Sitzungsber. Ges. nat. Freunde Berlin 1935: 50-69.

Reinig, W. F. (1937) Die Holarktis. Ein Beitrag zur diluvialen und alluvialen Geschichte der zirkumpolaren Fauen- und Florengebiete. Jena. Gustav Fischer.

Reinig, W. F. (1938) Elimination und Selektion. Eine Untersuchung über Merkmalsprogressionen bei Tieren und Pflanzen auf genetisch- und historisch-chorologischer Grundlage. Jena. Gustav Fischer.

Reinig, W.F. (1939a) Die Evolutionsmechanismen, erläutert an den Hummeln. Verh. Deutsch. Zool. Ges. Zool. Anz. 12: 170-206.

Reinig, W. F. (1939b) Die genetisch-chorologischen Grundlagen der gerichteten Variabilität. Z. indukt. Abst. u. Vererbungsl. 76: 260-308.

Rensch, B. (1928) Die stammesgeschichtliche Bedeutung geographischer Rassenkreise. Verh. Deutsch. Zool. Ges. 32: 79-88.

Rensch, B. (1929) Das Prinzip geographischer Rassenkreise und das Problem der Artbildung. Berlin. Borntraeger. 
Rensch, B. (1933) Zoologische Systematik und Artbildungsproblem. Verh. Deutsch. Zool. Ges. Suppl. 6: 19-83.

Rensch, B. (1934) Kurze Anweisung für zoologisch-systematische Studien. Leipzig. Akad. Verlagsges.

Rensch, B. (1939) Typen der Artbildung. Biol. Rev. 14: 180-222.

Rensch, B. (1943 a) Die paläontologischen Evolutionsregeln in zoologischer Betrachtung. Biol. General. 17: 1-55.

Rensch, B. (1943 b) Die biologischen Beweismittel der Abstammungslehre. In: Heberer, G. (ed) Die Evolution der Organismen. Jena. Gustav Fischer, pp 57-85.

Rensch, B. (1947) Neuere Probleme der Abstammungslehre. Die transspezifische Evolution. Stuttgart. Enke. 2d ed. 1954. 3d ed. 1972. English ed. Evolution above the Species Level. New York. Columbia University Press, 1960.

Rensch, B. (1951) Probleme der gerichteten Entwicklung und der Bauplanentstehung. Verh. Anat. Ges. Heidelberg, 49, Anat. Anz. 98, Erg. Heft 3.

Rensch, B. (1959) Die phylogenetische Abwandlung der Ontogenese. In: Heberer, G. (ed) Die Evolution der Organismen. 2d ed. Stuttgart. Gustav Fischer, pp 103-130.

Rensch, B. (1980) Historical development of the present synthetic neo-Darwinism in Germany. In: Mayr, E.; Provine, W. B. (eds) The Evolutionary Synthesis. Cambridge, Mass. Harvard University Press, pp 284-303.

Resnik, D. (1995) Developmental constraints and patterns: Some pertinent distinctions. J. Theor. Biol. 173: 231-240.

Rheinberger, H. J. (1997) Toward a History of Epistemic Things: Synthesizing Proteins in the Test Tube. Stanford. Stanford University Press.

Ridley, M. (1993) Evolution. Boston. Blackwell Scientific Publications.

Ridley, M. (ed) (1997) Evolution. Oxford. Oxford University Press.

Romanes, G. J. (1895) Darwin and after Darwin: An Exposition of the Darwinian Theory and a Discussion of Post-Darwinian Questions. Vol. 2, Post-Darwinian Questions: Heredity and Utility. Chicago. Open Court.

Ruse, M. (1971) Is the theory of evolution different ? I. The central core of the theory. II. The structure of the entire theory. Scientia 106: 765-783, 1089-1093.

Ruse, M. (1973). The Philosophy of Biology. London. Hutchinson.

Ruse, M. (1996) Monad to Man: The Concept of Progress in Evolutionary Biology. Cambridge/London. Harvard University Press.

Schindewolf, O. H. (1936) Paläontologie, Entwicklungslehre und Genetik. Kritik und Synthese. Berlin. Bornträger.

Schindewolf, O. H. (1945) Darwinismus oder Typostrophismus? Arbeiten des ungarischen biologischen Forschungsinstituts 16: 104-177.

Schindewolf, O. H. (1950) Grundfragen der Paläontologie. Organische Stammesentwicklung, Biologische Systematik. Stuttgart. Schweizerbart. English: Basic Questions in Paleontology. Edited by by J. Schaeffer, with a foreword by S. J. Gould and an afterword by W.-E. Reif. Chicago. Chicago University Press, 1993.

Schmalhausen, I. I. (1938) Organizm kak celoje v individualnom i istoriceskom razvitii. Moskva, Leningrad.

Schmalhausen, I. I. (1939) Puti i zakonomernosti evolucionnogo processa. Moskva, Leningrad.

Schmalhausen, I. I. (1946) Faktory evolucii. Moskva, Leningrad.

Schmalhausen, I. I. (1949) Factors of Evolution. The Theory of Stabilizing Selection. Foreword by Th. Dobzhansky. Chicago. The University of Chicago Press.

Schwanitz, F. (1943) Genetik und Evolutionsforchung bei Pflanzen. In: Heberer, G. (ed) Die Evolution der Organismen, Jena. Gustav Fischer, pp 430-478.

Schwenk, K. (1995) A utilitarian approach to evolutionary constraint. Zoology 98: 251262.

Senglaub, K. (1978) Vorgeschiche und Herausbildung der Synthetischen Theorie der Evolution und der Anteil der ornithologischen Systematik. Mitt. Zool. Mus. Berlin 54 (Ann. Ornithol. 2): 35-55.

Sepkoski, J. J. Jr. (1996) Competition in macroevolution: The double wedge revisited. In: Jablonski, D.; Erwin, D. H.; Lipps, J. H. (eds) Evolutionary Paleobiology. Chicago. University of Chicago Press, pp 211-255. 
Serebrovskij, A. S. (1927) Geneticeskij analiz populjacii domasnich kur gorcev Dagestana. K probleme genogeografii). Zhurnal eksperimental'noj biologii 3; Supply 1-2: 62-124; Supply 3-4: $125-146$.

Sewertzoff, A. N. (1931) Morphologische Gesetzmäßigkeiten der Evolution. Jena. Gustav Fischer.

Sewertzoff, S. A. (1941) Dinamika naselenija i prisposobitel'naja evolucijja shivotnych. Moskva, Leningrad.

Shapere, D. (1980) The meaning of the Evolutionary Synthesis. In: Mayr, E.; Provine, W. B. (eds) The Evolutionary Synthesis. Cambridge, Mass. Harvard University Press, pp 388398.

Simpson, G. G. (1937) Supra-specific variation in nature and in classification. Amer. Nat. 71: 236-267.

Simpson, G. G. (1944) Tempo and Mode in Evolution. New York. Columbia University Press. German Translation: Zeitmaße und Ablaufformen der Evolution. Göttingen. Musterschmidt, 1953.

Simpson, G. G. (1949a) The Meaning of Evolution. A Study of the History of Life and of its Significance for Man. New Haven. Yale University Press.

Simpson, G. G. (1949b) Essay-review of recent works on evolutionary theory by Rensch, Zimmermann, and Schindewolf. Evolution 3: 178-184.

Simpson, G. G. (1953) The Major Features of Evolution. New York. Columbia University Press.

Simpson, G. G. (1978) Concession to the Improbable: An Unconventional Autobiography. New Haven and London. Yale University Press.

Skelton, P. (1993) Evolution - A Biological and Palaeontological Approach. Wokingham. Addison-Wesley Publishing Company.

Smith, J. M.; Burian, R.; Kauffman, S. et al. (1985) Developmental constraints and evolution. Quart. Rev. Biol. 60(3): 265-287.

Smith, M. J. (1979) The Theory of Evolution. London. Penguin Books.

Smocovitis, V. B. (1992) Unifying biology: The evolutionary synthesis and evolutionary biology. Journ. Hist. Biol. 25: 1-65.

Smocovitis, V. B. (1996) Unifying Biology: The Evolutionary Synthesis and Evolutionary Biology. Princeton. Princeton University Press.

Sober, E. (1984) The Nature of Selection. Cambridge, Mass. MIT Press.

Sober, E. (1993) The Nature of Selection: Evolutionary Theory in Philosophical Focus. Chicago: University of Chicago Press.

Sober, E.; Wilson, D. S. (1998) Unto Others: The Evolution and Psychology of Unselfish Behavior. Cambridge, Mass. Harvard University Press.

Stanley, S. M. (1979) Macroevolution, Pattern and Process. San Francisco. W. H. Freeman \& Co.

Starck, D. (1965) Vergleichende Anatomie der Wirbeltiere von Gegenbaur bis heute. Verhandlungen der Deutschen Zoologischen Gesellschaft in Jena: 51-67.

Starck, D. (1980) Die idealistische Morphologie und ihre Nachwirkungen. Medizinhistorisches Journal 15: 44-56.

Stebbins, G. L. (1950) Variation and Evolution in Plants. New York. Columbia University Press.

Stebbins, G. L. (1959) The synthetic approach to organic evolution. Cold Spring Harbor Symp. Quant. Biol. 24: 305-311.

Stebbins, G. L. (1969) The Basis of Progressive Evolution. Chapel Hill. The Univ. of North Carolina Press.

Stebbins, G. L. (1971) Process of Organic Evolution. Englewood Cliffs. Prentice-Hall Inc.

Stebbins, G. L.; Ayala, F. J. (1985) The evolution of Darwinism. Scientific American 253: 5464.

Stebbins, G. L. (1980) Botany and the Synthetic Theory of Evolution. In: Mayr, E.; Provine, W. B. (eds) The Evolutionary Synthesis. Cambridge, Mass. Harvard University Press, pp 139-152.

Strathmann, R. R. (1975) Limitations on diversity of forms: Branching of ambulacral systems of echinoderms. Amer. Natur. 109: 177-190.

Stubbe, H. (1934) Die Bedeutung der Mutationen für die theoretische und angewandte Genetik. Die Naturwiss. 22: 781-787. 
Stubbe, H.; Wettstein, F. v. (1941) Über die Bedeutung von Klein- und Großmutationen in der Evolution. Biol. Zbl. 61: 265-297.

Sukacev, V. N. (1925) Eksperimental'naja fitosociologija i eë zadaci. Zapiski Leningradskogo sel'skochozjajstvennogo instituta 2: 174-186.

Sukacev, V. N. (1935) Opyt eksperimental'nogo izucenija meshbiotipnoj bor'by za suscestvovanie u rastenij. Trudy petergofskogo biologiceskogo instituta LGU 15: 69-86.

Suppe, F. (1977) The Structure of Scientific Theories. 2d ed. Urbana. University of Illinois Press.

Suppe, F. (1979) Theory structure. Current Res. Phil. Sci. East Lansing, Mich. Phil. Sci. Assoc. 317-338.

Suppe, F. (1988) The Semantic Conception of Theories and Scientific Realism. Urbana. University of Illinois Press.

Tax, S. (ed) (1960) The Evolution of Life: Its Origin, History and Future. Chicago. University of Chicago Press.

Thompson, P. (1980) The interaction of theories and the semantical conception of evolutionary theory. Philosophica 37: 28-37.

Thompson, P. (1983 a) The structure of evolutionary theory: a semantic perspective. Stud. Hist. Phil. Sci. 14: 215-229.

Thompson, P. (1983 b) Tempo and mode in evolution: Punctuated equilibria and the modern synthetic theory. Phil. Sci. 50: 432-452.

Thompson, P. (1987) A defense of the semantic conception of evolutionary theory. Biol. \& Philos. 2: 26-32.

Thompson, P. (1988) The Structure of Biological Theories. Albany, N. Y. State University of New York Press.

Timoféeff-Ressovsky, H. A.; Timoféeff-Ressovsky, N. W. (1927) Genetische Analyse einer freilebenden Drosophila melanogaster-Population. Roux' Archiv Entwicklungsmech. 109: 70-109.

Timoféeff-Ressovsky, N. W. (1937) Experimentelle Mutationsforschung in der Vererbungslehre. Dresden und Leipzig. Steinkopf.

Timoféeff-Ressovsky, N. W. (1939 a) Genetik und Evolution (Bericht eines Zoologen). Z. indukt. Abstamm. u. Vererbungsl. 76: 158-219.

Timoféeff-Ressovsky, N. W. (1939b). Genetik und Evolutionsforschung. Verh. Deutsch. Zool. Ges. Supplbd. 12 (Zool. Anz.): 157-169.

Timoféeff-Ressovsky, N. W. (1940) Mutations and geographical variations. In: Huxley, J. (ed) The New Systematics, pp 73-136.

Timoféeff-Ressovsky, N. W.; Timoféeff-Ressovsky, H. A. (1940) Populationsgenetische Versuche an Drosophila. I-III. Z. indukt. Abstammungs. u. Vererbungsl. 79: 28-34, 35-42, 44-51.

Timoféeff-Ressovsky, N. W.; Voroncov, N. N.; Jablokov, A. V. (1975) Kurzer Grundriß der Evolutionstheorie. Jena. VEB Gustav Fischer.

Tuomi, J. (1981) Structure and dynamics of Darwinian evolutionary theory. Syst. Zool. 30: 22-31.

Tuomi, J. (1992) Evolutionary synthesis: A search for the strategy. Phil. Sci. 59: 429-438.

Voroncov, N. N. (ed.) (1993) Nikolai Vladimirovitsch Timofeev-Ressovskij. Ocerki vospominanija materialy. Moskva, Nauka.

Vrba, E. S.; Eldredge, N. (1984) Individuals, hierarchies and processes: Towards a more complete evolutionary theory. Paleobiology 10: 146-171.

Wade, M. J. (1980 a) Wright's view of evolution. Science 207: 173-174.

Wagner, G. P.; Misof, B. Y. (1993) How can a character be developmentally constrained despite variation in developmental pathways? J. evol. Biol. 6: 449-455.

Wasserman, G. D. (1981) On the nature of the theory of evolution. Philos. Sci. 48: 416-437.

Wassermann, G. D. (1978) Testability of the role of natural selection within theories of population genetics and evolution. Brit. J. Phil. Sci. 29: 223-242.

Weber, M. (1998) Die Architektur der Synthese. Entstehung und Philosophie der modernen Evolutionstheorie. Berlin. Walter de Gruiter.

Weingart, P.; Kroll, J.; Bayertz, K. (1992) Rasse, Blut und Gene. Geschichte der Eugenik und Rassenhygiene in Deutschland. Frankfurt am Main. Suhrkamp.

Weismann, A. (1885) Die Kontinuität des Keimplasmas. Jena. Gustav Fischer.

Wettstein, F. v. (1939) Botanik, Paläobotanik, Vererbungsforschung und Abstammungslehre. Palaeobiologica 7: 154-168. 
Wettstein, R. v. (1928) Das Problem der Evolution und die moderne Vererbungslehre. Z. ind. Abstammungs- und Vererbungslehre Suppl. Band 1: 370-380.

Williams, M. B. (1970) Deducing the consequences of evolution: a mathematical model. J. Theoret. Biol. 29: 343-385.

Williams, M. B. (1973 a) Falsifiable predictions of evolutionary theory. Phil. Sci. 40: 518-537.

Williams, M. B. (1973 b) The logical status of the theory of natural selection and other evolutionary controversies. In: Bunge, M. (ed) The Methodological Unity of Science. Dordrecht. Reidel, pp 84-102.

Williams, M. B. (1981) Similarities and differences between evolutionary theory and the theories of physics. Philos. Soc. Amer. 1980, 2: 385-396.

Wilson, D. S. (1992) Group Selection. In: Keller, E. F.; Lloyd, E. A. (eds) Keywords in Evolutionary Biology. Cambridge, Mass. Harvard University Press, pp 145-148.

Wimsatt, W. C. (1986) Developmental constraints, generative entrenchment, and the innateacquired distinction. In: Bechtel, W. (ed) Integrating Scientific Disciplines. Dordrecht. Nijhoff, pp 185-208.

Wright, S. (1921) Systems of mating. Genetica 6: 111-178.

Wright, S. (1929) Fisher's theory of dominance. Amer. Nat. 63: 274.

Wright, S. (1931 a) Evolution in Mendelian populations. Amer. Nat. 92: 329-335.

Wright, S. (1931 b) Evolution in Mendelian populations. Genetics 16: 97-159.

Wright, S. (1932) The roles of mutation, inbreeding, crossbreeding, and selection in evolution. Proc. 6th. Int. Congr. Genet. 1: 356-66.

Wright, S. (1945) Tempo and mode in evolution: A critical review. Ecology 26: 415-419.

Wright, S. (1960) Genetics and twentieth century Dawinism: A review and discussion. Amer. Journ. Human Genetics 12: 365-372.

Wright, S. (1967) The foundation of population genetics. In: Brink, R. A. (ed) Heritage from Mendel. Madison. Univ. Wisconsin Press, pp 245-263.

Zachos, F.; Hoßfeld, U. (2000): Adolf Remane (1898-1976): Biographie und ausgewählte evolutionsbiologische Aspekte in seinem Werk. In: Hoßfeld, U.; Brömer, R. (eds) Darwinismus und/als Ideologie. Verhandlungen zur Geschichte und Theorie der Biologie, Bd. 6. Berlin. Verlag für Wissenschaft und Bildung. (in prep.)

Zavadskij, K. M. (1974) Istorija i teorija evolucionnogo ucenija: evolucionnye vzglady I. I. Smalgauzena (k 90-e letiju so dnja rozdenija). IIET AN SSSR, Leningrad.

Zavadskij, K. M.; Kolchinsky, E. I. (1977) Evolucija evolucii. Istoriko-kriticeskije ocerki problemy. Leningrad.

Zimmermann, W. (1928) Kritische Bemerkungen zu einigen biologischen Problemen. II: Zweckmäßige Eigenschaften und Phylogenie. Biol. Zentralbl. 48: 203-229.

Zimmermann, W. (1930) Die Phylogenie der Pflanzen, ein Überblick über Tatsachen und Probleme. Jena. Gustav Fischer. 2d ed. 1959.

Zimmermann, W. (1934 a) Grundfragen der Deszendenzlehre. In: Moderne Naturwissenschaft, Öffentl. Vortr. Univ. Tübingen, WS 1933/34. Stuttgart. Kohlhammer, pp 183216.

Zimmermann, W. (1934 b) Research on phylogeny of species and of single characters. Amer. Natur. 68: 381.

Zimmermann, W. (1934-1935) Genetische Untersuchungen an Pulsatilla I-III. Flora N. F. 129: 158-234.

Zimmermann, W. (1938) Vererbung erworbener Eigenschaften und Auslese. Jena. Gustav Fischer. $2 \mathrm{~d}$ ed. 1969.

Zimmermann, W. (1943) Die Methoden der Phylogenetik. In: Heberer, G. (ed) Die Evolution der Organismen. Jena. Gustav Fischer, pp 20-56.

Zimmermann, W. (1948) Grundfragen der Evolution. Frankfurt. Vittorio Klostermann.

Zimmermann, W. (1953) Evolution: Die Geschichte ihrer Probleme und Erkenntnisse. Freiburg and München. Karl Alber.

Zündorf, W. (1939): Der Lamarckismus in der heutigen Biologie. Archiv für Rassen- und Gesellschafts-Biologie 33: 281-303.

Zündorf, W. (1940): Phylogenetische oder Idealistische Morphologie. Der Biologe 9: 10-24.

Zündorf, W. (1942): Nochmals: Phylogenetik und Typologie. Der Biologe 11: 125-129.

Zündorf, W. (1943) Idealistische Morphologie und Phylogenetik. In: Heberer, G. (ed) Die Evolution der Organismen. Jena. Gustav Fischer, pp 86-104. 